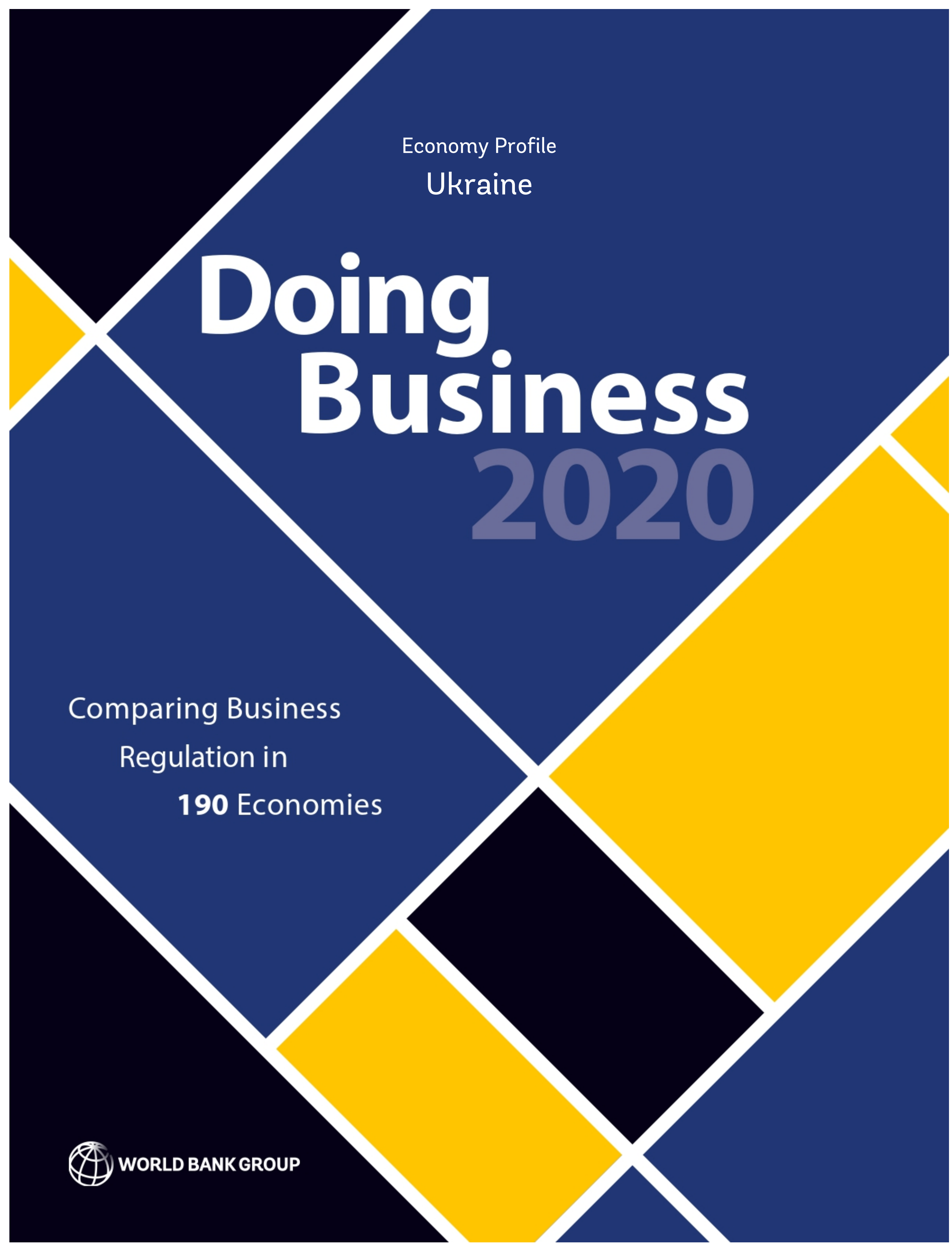




\section{Economy Profile of Ukraine}

Doing Business 2020 Indicators

(in order of appearance in the document)

Starting a business

Procedures, time, cost and paid-in minimum capital to start a limited liability company

Dealing with construction permits

Procedures, time and cost to complete all formalities to build a warehouse and the quality control and safety mechanisms in the construction permitting system

Getting electricity

Procedures, time and cost to get connected to the electrical grid, and the reliability of the electricity supply and the transparency of tariffs

Registering property

Procedures, time and cost to transfer a property and the quality of the land administration system

Getting credit

Movable collateral laws and credit information systems

Protecting minority investors

Minority shareholders' rights in related-party transactions and in corporate governance

Paying taxes

Payments, time, total tax and contribution rate for a firm to comply with all tax regulations as well as postfiling processes

Trading across borders

Time and cost to export the product of comparative advantage and import auto parts

Enforcing contracts

Time and cost to resolve a commercial dispute and the quality of judicial processes

Resolving insolvency

Time, cost, outcome and recovery rate for a commercial insolvency and the strength of the legal framework for insolvency 


\section{About Doing Business}

The Doing Business project provides objective measures of business regulations and their enforcement across 190 economies and selected cities at the subnational and regional level.

The Doing Business project, launched in 2002, looks at domestic small and medium-size companies and measures the regulations applying to them through their life cycle.

Doing Business captures several important dimensions of the regulatory environment as it applies to local firms. It provides quantitative indicators on regulation for starting a business, dealing with construction permits, getting electricity, registering property, getting credit, protecting minority investors, paying taxes, trading across borders, enforcing contracts and resolving insolvency. Doing Business also measures features of employing workers. Although Doing Business does not present rankings of economies on the employing workers indicators or include the topic in the aggregate ease of doing business score or ranking on the ease of doing business, it does present the data for these indicators.

By gathering and analyzing comprehensive quantitative data to compare business regulation environments across economies and over time, Doing Business encourages economies to compete towards more efficient regulation; offers measurable benchmarks for reform; and serves as a resource for academics, journalists, private sector researchers and others interested in the business climate of each economy.

In addition, Doing Business offers detailed subnational studies, which exhaustively cover business regulation and reform in different cities and regions within a nation. These studies provide data on the ease of doing business, rank each location, and recommend reforms to improve performance in each of the indicator areas. Selected cities can compare their business regulations with other cities in the economy or region and with the 190 economies that Doing Business has ranked.

The first Doing Business study, published in 2003, covered 5 indicator sets and 133 economies. This year's study covers 11 indicator sets and 190 economies. Most indicator sets refer to a case scenario in the largest business city of each economy, except for 11 economies that have a population of more than 100 million as of 2013 (Bangladesh, Brazil, China, India, Indonesia, Japan, Mexico, Nigeria, Pakistan, the Russian Federation and the United States) where Doing Business also collected data for the second largest business city. The data for these 11 economies are a population-weighted average for the 2 largest business cities. The project has benefited from feedback from governments, academics, practitioners and reviewers. The initial goal remains: to provide an objective basis for understanding and improving the regulatory environment for business around the world.

To learn more about Doing Business please visit doingbusiness.org 
Ease of Doing Business in Ukraine

\begin{tabular}{ll} 
Region & Europe \& Central Asia \\
\hline Income Category & Lower middle income \\
\hline Population & $44,622,516$ \\
\hline City Covered & Kyiv
\end{tabular}

DB RANK

DB SCORE

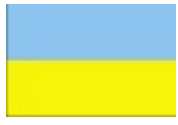

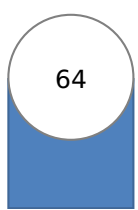
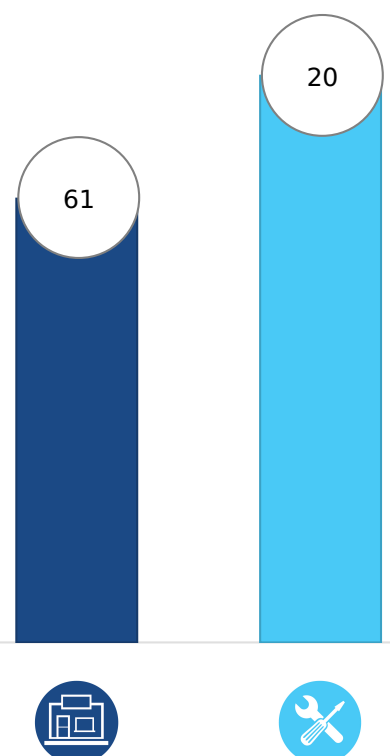

Starting a

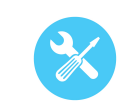

Dealing Dealing
with Construction Permits

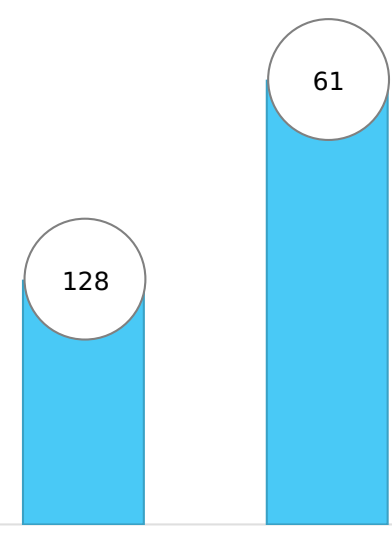

Getting
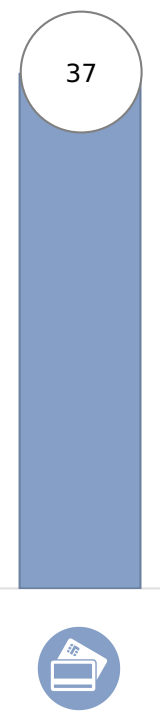

Getting
Credit
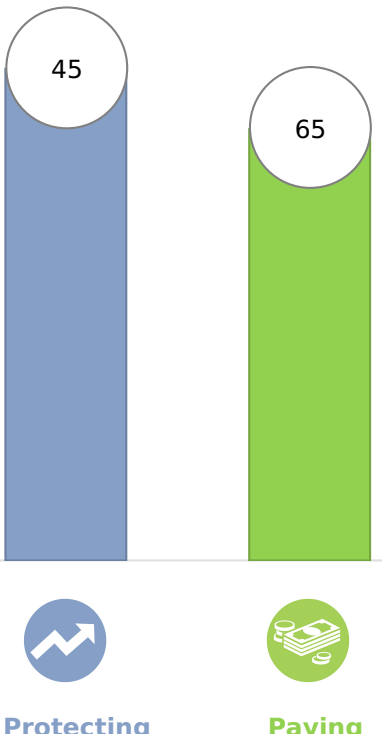

Paying
Taxes Protecting
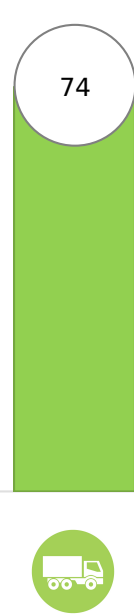

Trading across
Borders
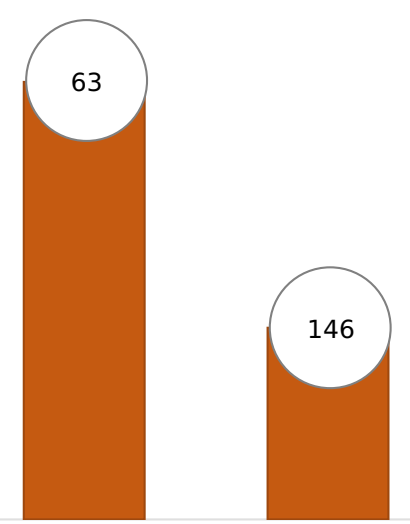

III Enforcing
Contracts Minority
Investors

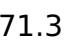

\section{5}

71.3

\section{1}

62.5

Starting a Business (rank)

Score of starting a business (0-100)

Procedures (number)

Time (days)

Cost (number)

Paid-in min. capital (\% of income per capita)

Dealing with Construction Permits (rank)

Score of dealing with construction permits (0-100)

Procedures (number)

Time (days)

Cost (\% of warehouse value)

Building quality control index (0-15)

$\checkmark$ Getting Electricity (rank)

Score of getting electricity (0-100)

Procedures (number)

Time (days)

Cost (\% of income per capita)

Reliability of supply and transparency of tariff index (0-8)

$\checkmark$ Registering Property (rank)

Score of registering property (0-100)

Procedures (number)

Time (days)

Cost (\% of property value)

\section{1}

91.1

6

0.0

20

81.1

10

72.5

4.4

12.0

128

62.5

53.2

7 71.3

7

15

1.7

16.0
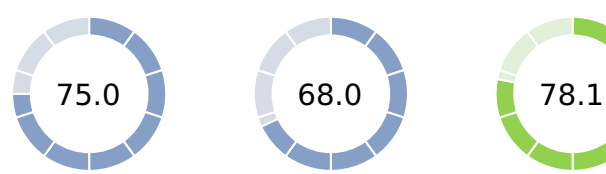

78.1

Getting Credit (rank)

Score of getting credit (0-100)

Strength of legal rights index (0-12)

Depth of credit information index (0-8)

Credit registry coverage (\% of adults)

Credit bureau coverage ( $\%$ of adults)

Protecting Minority Investors (rank)

Score of protecting minority investors (0-100) Extent of disclosure index (0-10)

Extent of director liability index (0-10)

Ease of shareholder suits index (0-10)

Extent of shareholder rights index (0-6)

Extent of ownership and control index (0-7)

Extent of corporate transparency index (0-7)

Paying Taxes (rank)

Score of paying taxes (0-100)

Payments (number per year)

Time (hours per year)

Total tax and contribution rate (\% of profit)

Postfiling index (0-100)
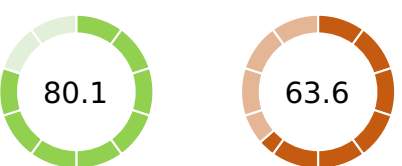

31.4 74 Score of trading across borders (0-100) 80.1

Time to export

Documentary compliance (hours) $\quad 66$

Border compliance (hours)

Cost to export

Documentary compliance (USD) 192

Border compliance (USD)

Time to import

Documentary compliance (hours) $\quad 48$

Border compliance (hours) 32

Cost to import

Documentary compliance (USD) 162

Border compliance (USD)

Enforcing Contracts (rank) 63

Score of enforcing contracts (0-100) $\quad 63.6$

Time (days) 378

Cost (\% of claim value) $\quad 46.3$

Quality of judicial processes index (0-18) 11.5

Resolving Insolvency (rank) 146

Score of resolving insolvency (0-100) 31.4

Recovery rate (cents on the dollar) $\quad 9.0$

Time (years) $\quad 2.9$

Cost (\% of estate) $\quad 40.5$

Outcome ( 0 as piecemeal sale and 1 as going $\quad 0$

concern)

8.5 


\section{Starting a Business}

This topic measures the number of procedures, time, cost and paid-in minimum capital requirement for a small- to medium-sized limited liability company to start up and formally operate in each economy's largest business city.

To make the data comparable across 190 economies, Doing Business uses a standardized business that is $100 \%$ domestically owned, has start-up capital equivalent to 10 times the income per capita, engages in general industrial or commercial activities and employs between 10 and 50 people one month after the commencement of operations, all of whom are domestic nationals. Starting a Business considers two types of local limited liability companies that are identical in all aspects, except that one company is owned by 5 married women and the other by 5 married men. The ranking of economies on the ease of starting a business is determined by sorting their scores for starting a business. These scores are the simple average of the scores for each of the component indicators.

The most recent round of data collection for the project was completed in May 2019. See the methodology for more information.

\section{What the indicators measure}

\section{Procedures to legally start and formally operate a company} (number)

- Preregistration (for example, name verification or reservation, notarization)

- Registration in the economy's largest business city

- Postregistration (for example, social security registration, company seal)

- Obtaining approval from spouse to start a business or to leave the home to register the company

- Obtaining any gender specific document for company registration and operation or national identification card

\section{Time required to complete each procedure (calendar days)}

- Does not include time spent gathering information

- Each procedure starts on a separate day (2 procedures cannot start on the same day)

- Procedures fully completed online are recorded as $1 / 2$ day

- Procedure is considered completed once final document is received

- No prior contact with officials

Cost required to complete each procedure ( $\%$ of income per capita)

- Official costs only, no bribes

- No professional fees unless services required by law or commonly used in practice

\section{Paid-in minimum capital (\% of income per capita)}

- Funds deposited in a bank or with third party before registration or up to 3 months after incorporation

\section{Case study assumptions}

To make the data comparable across economies, several assumptions about the business and the procedures are used. It is assumed that any required information is readily available and that the entrepreneur will pay no bribes.

\section{The business:}

-Is a limited liability company (or its legal equivalent). If there is more than one type of limited liability company in the economy, the limited liability form most common among domestic firms is chosen. Information on the most common form is obtained from incorporation lawyers or the statistical office.

-Operates in the economy's largest business city. For 11 economies the data are also collected for the second largest business city.

-Performs general industrial or commercial activities such as the production or sale to the public of goods or services. The business does not perform foreign trade activities and does not handle products subject to a special tax regime, for example, liquor or tobacco. It is not using heavily polluting production processes.

-Does not qualify for investment incentives or any special benefits.

-Is $100 \%$ domestically owned.

-Has five business owners, none of whom is a legal entity. One business owner holds $30 \%$ of the company shares, two owners have $20 \%$ of shares each, and two owners have $15 \%$ of shares each.

-Is managed by one local director.

-Has between 10 and 50 employees one month after the commencement of operations, all of them domestic nationals.

-Has start-up capital of 10 times income per capita.

-Has an estimated turnover of at least 100 times income per capita.

-Leases the commercial plant or offices and is not a proprietor of real estate.

-Has an annual lease for the office space equivalent to one income per capita.

Is in an office space of approximately 929 square meters (10,000 square feet)

-Has a company deed that is 10 pages long.

\section{The owners:}

-Have reached the legal age of majority and are capable of making decisions as an adult. If there is no legal age of majority, they are assumed to be 30 years old.

-Are in good health and have no criminal record.

-Are married, the marriage is monogamous and registered with the authorities.

Where the answer differs according to the legal system applicable to the woman or man in question (as may be the case in economies where there is legal plurality), the answer used will be the one that applies to the majority of the population. 


\section{Starting a Business - Ukraine}

\section{Standardized Company}

\section{Legal form}

Paid-in minimum capital requirement

City Covered

Indicator

Procedure - Men (number)

Time - Men (days)

6.5

6.5

0.5

Ukraine

Cost - Men (\% of income per capita)

OECD high income
Tovarystvo z Obmezhenoyu Vidpovidalnistyu - Limited Liability Company

No minimum

Procedure - Women (number)

Time - Women (days)

Cost - Women (\% of income per capita)

Paid-in min. capital (\% of income per capita)

5

Kyiv

Figure - Starting a Business in Ukraine - Score

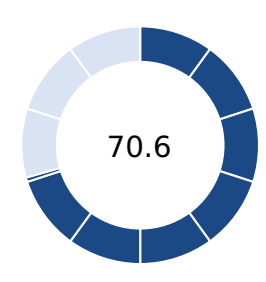

Procedures

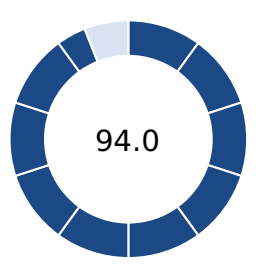

Time

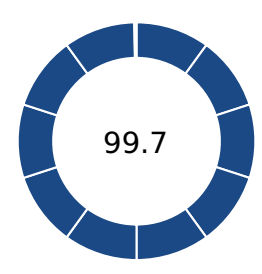

Cost

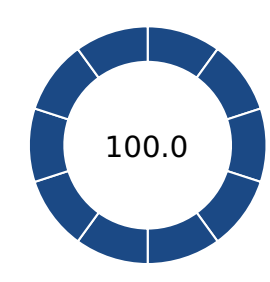

Paid-in min. capital

Figure - Starting a Business in Ukraine and comparator economies - Ranking and Score

DB 2020 Starting a Business Score

$\mathbf{0}$

99.6: Georgia (Rank: 2)

95.7: Moldova (Rank: 13)

94.4: Kazakhstan (Rank: 22)

93.5: Belarus (Rank: 30)

91.1: Ukraine (Rank: 61)

90.5: Regional Average (Europe \& Central Asia)

Note: The ranking of economies on the ease of starting a business is determined by sorting their scores for starting a business. These scores are the simple average of the scores for each of the component indicators. 


\section{Figure - Starting a Business in Ukraine - Procedure, Time and Cost}

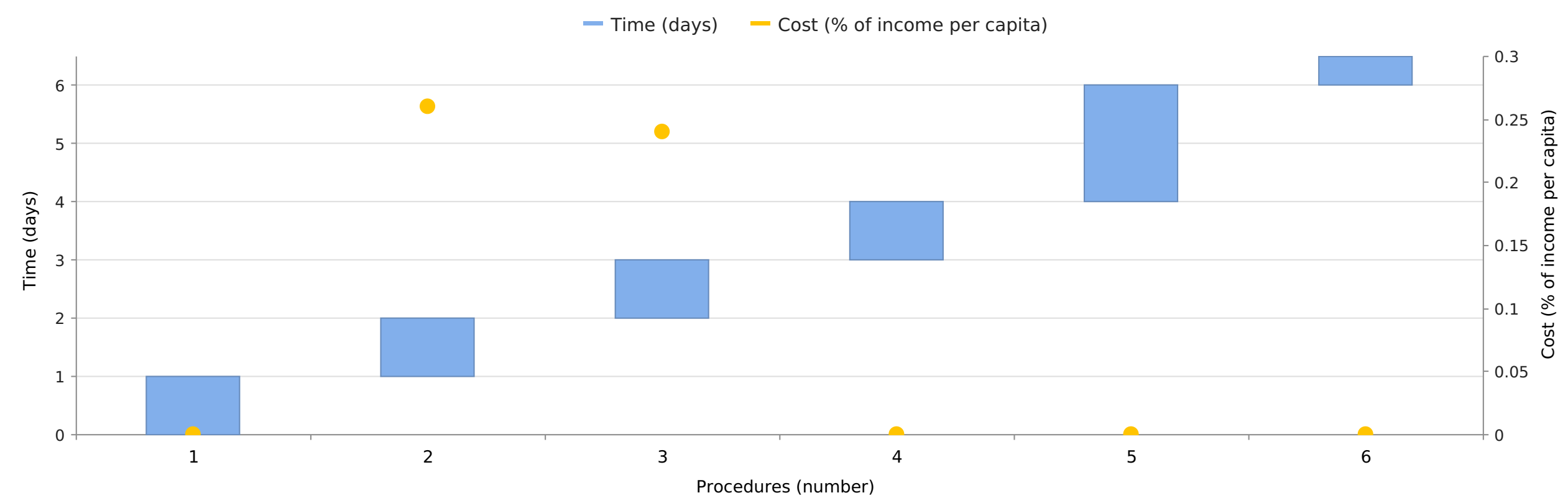

*This symbol is shown beside procedure numbers that take place simultaneously with the previous procedure.

Note: Online procedures account for 0.5 days in the total time calculation. For economies that have a different procedure list for men and women, the graph shows the time for women. For more information on methodology, see the Doing Business website (http://doingbusiness.org/en/methodology). For details on the procedures reflected here, see the summary below. 
Details - Starting a Business in Ukraine - Procedure, Time and Cost

No. Procedures

Time to Complete

Agency: State Registrar, Notary

Currently, the LLC founders to enforce its registration must submit to the registrar or notary the following documents according to Art. 17 of the Law of Ukraine "On State Registration of Legal Entities, Individual Entrepreneurs and Public Formations" No.755-IV, dated May 15, 2003 :

- Form 1 "Application for registration of legal entity" (format approved by the order of Ministry of Justice of Ukraine dated 18 November 2016 No.3268/5 as amended by the order of Ministry of Justice of Ukraine dated 29 August 2018 №2824/5);

- original or notarized copy of the decision of founders on establishment of the entity (Minutes of General Meeting of Participants);

- LLC company's charter executed by the founders;

- the founder's meeting minutes.

Information on ultimate beneficial owners, as well as the type of holding and all legal entities through which the holding is conducted (in case its indirect) shall be indicated in the application for registration. Registration of an LLC with social security authorities, state statistics, state tax authorities is performed automatically in course of the state registration - the data is transferred by the registrar to the relevant state authorities.

Online registration system (https://kap.minjust.gov.ua/, http://rp.irc.gov.ua/) is available, however not popular due to a complicated procedure for submitting the documents online.

Additionally, application for voluntary VAT registration may be attached to the incorporation application. In this case, an electronic (scanned) copy of the registration application shall be transferred by the state registrar to the controlling bodies simultaneously with the information from the Unified State Register of Legal Entities.

\section{Prepare a seal}

Agency : Sealmaker

According to the Law of Ukraine "On making amendments to some legislative acts of Ukraine regarding usage of seals by legal entities and individuals entrepreneurs" No. 1982-VIII as of 23.03.2017 (https://zakon.rada.gov.ua/laws/show/1982-19), a legal entity may use a seal in its activities, however, it is not obligatory. Moreover, it is indicated that absence or presence of a seal's print on the documents does not lead to any legal consequences. Nevertheless the legislative base of Ukraine has not been utterly brought into conformity with these provisions, i.e. some normative acts still require a seal - that is why a seal is a widely use in practice. However, the state and local authorities, banks and notaries generally accept documents that are not certified with a company seal. Though in some cases they may request a duly certified copy of the company's document containing resolution to not use a company seal (e.g., the company's charter, respective resolution of the highest governing body, etc.)

\section{Agency: Notary}

Notarized signature card is required to open a bank account. According to Section 7 of Chapter 7 the Procedure for Making of Notarial Actions by Notaries of Ukraine, approved by the Order of the Ministry of Justice of Ukraine No. 296/5 dated 22 February 2012, as amended (available at: https://zakon.rada.gov.ua/laws/show/z0282-12), to notarize a specimen signature card, an authorized person shall submit to a notary the documents evidencing his/her right to represent the company and execute documents on its behalf (e.g., a copy of the order on appointment of the authorized person, a copy of the GPM Minutes on election of the authorized person, or a Power of Attorney issued for such authorized person, etc.). As the notary shall also check the legal capacity of the legal entity according to the indicated Order, he/she may also request relevant documents (for instance, the Charter of an LLC, Extract from the Unified State Register of Legal Entities, Individual Entrepreneurs and Non-Governmental Organizations, Excerpt on registration of establishment of an LLC, etc.).
No charge if performed at the State Registrar; Notary fee is due if done at the Notary's 
Agency : Bank

According to the Regulation of the National Bank of Ukraine No. 492 dated November 12, 2003 on

Approval of the Instruction "On the order of opening, use and closure of accounts in local and foreign currencies" (with amendments), the list of required documents for opening of the bank account for the Legal Entity includes:

- the copy of the charter of the LLC (simple copy certified by the director of the LLC or notarized copy);

- a notarized signature card or a notarized copy of the signature card;

- completed bank questionnaire;

- completed application form(s) to open a bank account(s), as well as to activate the online banking system;

- signed bank account agreement, etc. (depends on the requirements of the particular bank); - due to anti-money laundering rules, the bank will require disclosure of the whole group structure of the founder(s) down to the natural persons who are the ultimate beneficial owners of the founder(s) (if any).

The above list of information/documents is not exhaustive and may be changed due to the requirements of the specific bank. In case the incorporation of a company was done electronically, no paper version of the charter should be submitted.

According to the Notification Order, on the day of the bank account opening the bank shall notify the State Fiscal Service of Ukraine via electronic sources using reliable means of electronic digital signature regarding this (https://zakon.rada.gov.ua/laws/show/z1058-15). After receiving the electronic notification through the Internet portal, within 1 business day a local tax authority shall notify the bank about registration of the account/refusal to register the account (if applicable). An LLC may use its account for outflow operations only after the bank receives the tax authorities' notification on registration of the respective account.

\begin{abstract}
Register VAT at the State Tax Authority and obtain a VAT number
Agency: District Tax Office

As defined in Law No. 71-VIII On Amendments to the Tax Code of Ukraine and some Legislative Acts of Ukraine Concerning Tax Reform which went into effect on January 1, 2015, if the total amount of transactions with delivery of goods or/and services, including the use of local or global computer network, charged (paid) during last 12 calendar months, totally exceeds UAH 1 million (excluding VAT), such company is obliged to register as VAT taxpayer, except single tax payer company. Actually, Art. 182 of the above mentioned Tax Code also provides option for voluntarily VAT taxpayer registration.
\end{abstract}

Application on voluntary registration of a VAT payer may be submitted simultaneously with the state registration of a legal entity. The state registrar or notary submits electronic copy of such an application to the District Tax Office together with the information from the Unified State Register of Legal Entities, Individual Entrepreneurs and Public Organisations on the registration of a legal entity.

The Government of Ukraine issued an Order of the Ministry of Finance № 185/26630 “On Amendments to the Regulation on registration of taxpayers VAT" on February 2, 2015, which came into effect on March 30, 2015. The aforementioned order stipulates that the VAT registration shall be made within 3 working days after filing the registration statement to the state authority.

As of now, it is possible to submit application for the registration as a VAT taxpayer online using electronic cabinet maintained by State Fiscal Service of Ukraine (https://cabinet.sfs.gov.ua/), where the application form may be submitted. Such online registration as a VAT-payer can not be carried before the company's registration. To be able to apply for VAT registration online, the company or its authorized representative has to enter into the agreement with the District Office of the State Fiscal Service of Ukraine on acknowledgment of the use of electronic documents in the first place. Furthermoe, the company has to obtain electronic signature.

\section{$6 \quad$ Register employees with the State Fiscal Service}

Agency: State Fiscal Service

According to Article 24 of the Labor Code of Ukraine, an employer is obliged to notify local tax authority of hiring an employee at least one day prior to commencement of work. The procedure for notification was set by the Regulation of the Cabinet of Ministers of Ukraine no. 413 dated 17 June 2015. The notification can be done in one of the following forms:

1) by filing a filled form to the local tax authority;

2) by both filling a filled form to the local tax authority and a digital copy of the form

3) by filing a filled electronic form using electronic digital signature.

Most companies use online systems to notify tax authorities about employment.
Less than a day (online no charge procedure)

$\rightarrow$ Takes place simultaneously with previous procedure. 


\section{Dealing with Construction Permits}

This topic tracks the procedures, time and cost to build a warehouse-including obtaining necessary the licenses and permits, submitting all required notifications, requesting and receiving all necessary inspections and obtaining utility connections. In addition, the Dealing with Construction Permits indicator measures the building quality control index, evaluating the quality of building regulations, the strength of quality control and safety mechanisms, liability and insurance regimes, and professional certification requirements. The most recent round of data collection was completed in May 2019. See the methodology for more information

What the indicators measure

\section{Procedures to legally build a warehouse (number)}

- Submitting all relevant documents and obtaining all necessary clearances, licenses, permits and certificates

- Submitting all required notifications and receiving all necessary inspections

- Obtaining utility connections for water and sewerage

- Registering and selling the warehouse after its completion

\section{Time required to complete each procedure (calendar days)}

- Does not include time spent gathering information

- Each procedure starts on a separate day-though procedures that can be fully completed online are an exception to this rule

- Procedure is considered completed once final document is received

- No prior contact with officials

\section{Cost required to complete each procedure (\% of income per} capita)

- Official costs only, no bribes

\section{Building quality control index (0-15)}

- Quality of building regulations (0-2)

- Quality control before construction (0-1)

- Quality control during construction (0-3)

- Quality control after construction (0-3)

- Liability and insurance regimes (0-2)

- Professional certifications (0-4)

\section{Case study assumptions}

To make the data comparable across economies, several assumptions about the construction company, the warehouse project and the utility connections are used.

\section{The construction company (BuildCo):}

- Is a limited liability company (or its legal equivalent) and operates in the economy's largest business city. For 11 economies the data are also collected for the second largest business city. - Is $100 \%$ domestically and privately owned; has five owners, none of whom is a legal entity. Has a licensed architect and a licensed engineer, both registered with the local association of architects or engineers. BuildCo is not assumed to have any other employees who are technical or licensed experts, such as geological or topographical experts.

- Owns the land on which the warehouse will be built and will sell the warehouse upon its completion.

\section{The warehouse:}

- Will be used for general storage activities, such as storage of books or stationery.

- Will have two stories, both above ground, with a total constructed area of approximately 1,300.6 square meters (14,000 square feet). Each floor will be 3 meters ( 9 feet, 10 inches) high and will be located on a land plot of approximately 929 square meters (10,000 square feet) that is $100 \%$ owned by BuildCo, and the warehouse is valued at 50 times income per capita. - Will have complete architectural and technical plans prepared by a licensed architect. If preparation of the plans requires such steps as obtaining further documentation or getting prior approvals from external agencies, these are counted as procedures.

- Will take 30 weeks to construct (excluding all delays due to administrative and regulatory requirements).

\section{The water and sewerage connections:}

- Will be 150 meters (492 feet) from the existing water source and sewer tap. If there is no water delivery infrastructure in the economy, a borehole will be dug. If there is no sewerage infrastructure, a septic tank in the smallest size available will be installed or built

- Will have an average water use of 662 liters (175 gallons) a day and an average wastewater flow of 568 liters ( 150 gallons) a day. Will have a peak water use of 1,325 liters ( 350 gallons) a day and a peak wastewater flow of 1,136 liters ( 300 gallons) a day.

- Will have a constant level of water demand and wastewater flow throughout the year; will be 1 inch in diameter for the water connection and 4 inches in diameter for the sewerage connection. 


\section{Dealing with Construction Permits - Ukraine}

\section{Standardized Warehouse}

Estimated value of warehouse

UAH 4,108,595.50

City Covered

Kyiv

\begin{tabular}{|c|c|c|c|c|}
\hline Indicator & Ukraine & $\begin{array}{l}\text { Europe \& Central } \\
\text { Asia }\end{array}$ & $\begin{array}{l}\text { OECD high } \\
\text { income }\end{array}$ & $\begin{array}{l}\text { Best Regulatory } \\
\text { Performance }\end{array}$ \\
\hline Procedures (number) & 10 & 16.2 & 12.7 & None in $2018 / 19$ \\
\hline Time (days) & 72.5 & 170.1 & 152.3 & None in 2018/19 \\
\hline Cost (\% of warehouse value) & 4.4 & 4.0 & 1.5 & None in $2018 / 19$ \\
\hline Building quality control index (0-15) & 12.0 & 12.1 & 11.6 & 15.0 (6 Economies) \\
\hline
\end{tabular}

Figure - Dealing with Construction Permits in Ukraine - Score

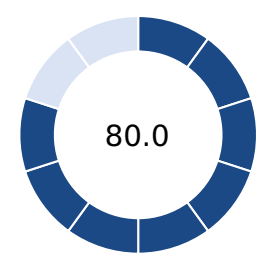

Procedures

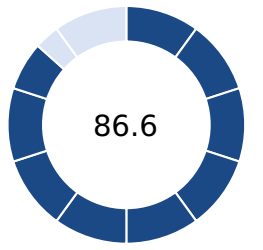

Time

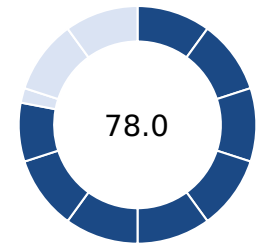

Cost

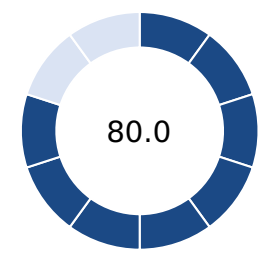

Building quality control index

Figure - Dealing with Construction Permits in Ukraine and comparator economies - Ranking and Score

DB 2020 Dealing with Construction Permits Score

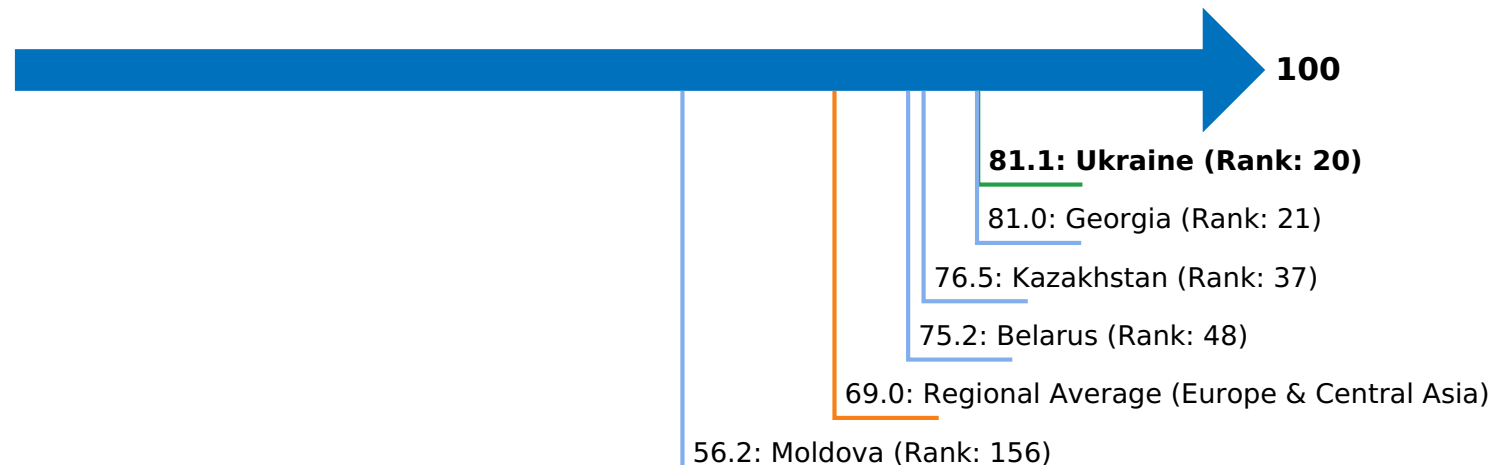

Note: The ranking of economies on the ease of dealing with construction permits is determined by sorting their scores for dealing with construction permits. These scores are the simple average of the scores for each of the component indicators. 
Figure - Dealing with Construction Permits in Ukraine - Procedure, Time and Cost

- Time (days) $\quad$ Cost (\% of warehouse value)

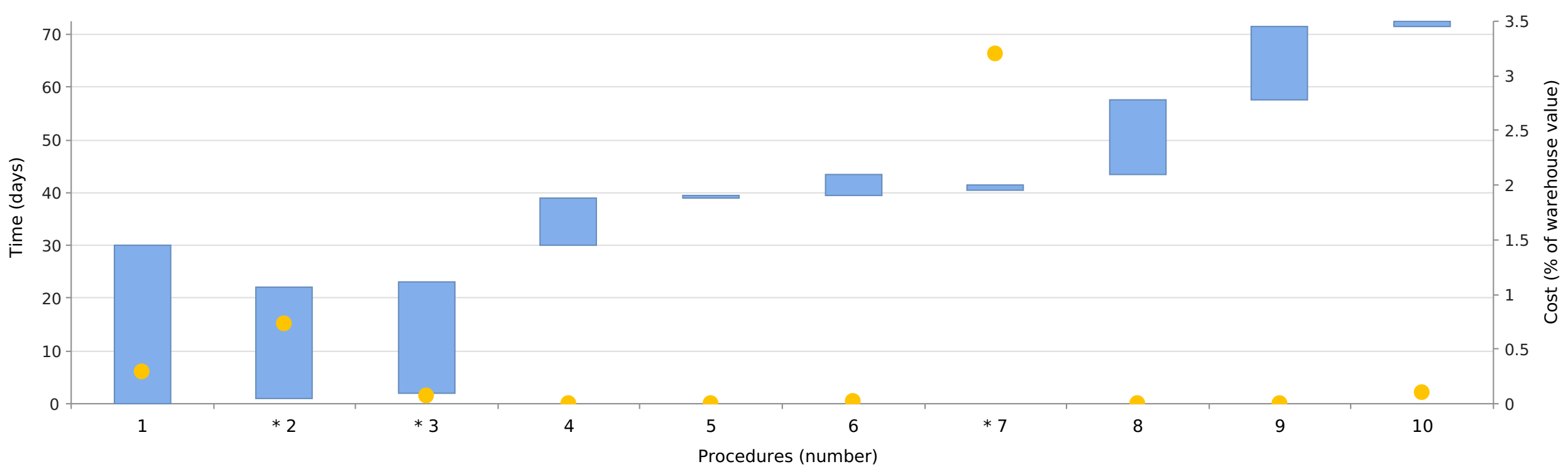

*This symbol is shown beside procedure numbers that take place simultaneously with the previous procedure.

Note: Online procedures account for 0.5 days in the total time calculation. For economies that have a different procedure list for men and women, the graph shows the time for women. For more information on methodology, see the Doing Business website (http://doingbusiness.org/en/methodology). For details on the procedures reflected here, see the summary below. 


\section{Figure - Dealing with Construction Permits in Ukraine and comparator economies - Measure of Quality}

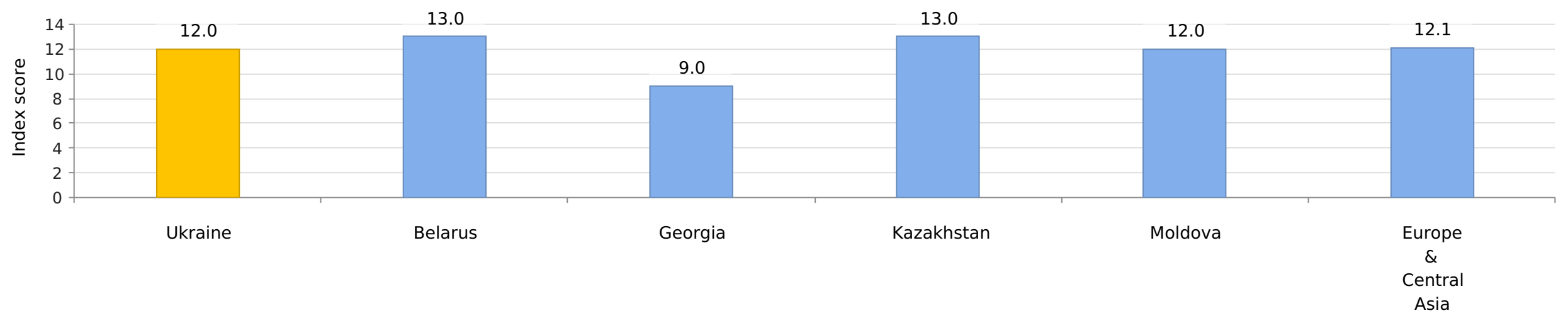

Details - Dealing with Construction Permits in Ukraine - Procedure, Time and Cost

Agency: Private licensed company

BuildCo must obtain a land survey at a scale of $1: 500 / 1$ by a specialized organization. A report is

prepared as a result of the topographic survey with a layout of the building and structure.

\section{$\rightarrow 2$ Obtain a geological survey of the land plot}

BuildCo must hire a private company to obtain a geological survey of the land plot.

$\rightarrow 3 \quad$ Request and obtain technical conditions from water and sewage authority

The application must include the plan, information on the expected volume of water and sewerage system use, and basic characteristics of the building.

A fee estimated to UAH 2,895.00 might be paid by BuildCo. The calculation of such fees is based on estimated labor expenditures in accordance with the Rules on using the central sewage and water supply systems as approved by Order of Ministry of Housing and Communal Services of Ukraine No. 190, from June 27, 2008 as further amended.

\section{Request and obtain urban planning specifications and requirements for land plot development}

Agency: Department of Urban Development and Architecture of Kiev City Administration

According to Article 29 of the Law of Ukraine "On the Regulation of Urban Development Activities", the town-planning conditions and restrictions for the development of the land plot, together with the technical conditions and design assignment, are part of the initial data for planning the construction site. To obtain the town-planning conditions and restrictions for the development of the land plot, BuildCo applies to the City Planning and Architecture Department of the executive body of the Kiev City Council (Kiev City State Administration) through the administrative services center and submits the following documents:

- Copy from the topographic and geodetic plan M 1: 2000

- Extract from the State Land Cadastre

- Application for granting town-planning conditions and restrictions for the design of the construction site

- A copy of the document certifying the ownership of the immovable property located on the land plot

- A copy of the document certifying the ownership or use of the land plot, or a copy of the superficies agreement.

- Urban planning with the technical and economic indicators of the planned construction site.

Provision of town-planning conditions and restrictions or a decision to refuse to provide them is carried out within 10 working days from the date of registration of the application.

Information on the provided town-planning conditions and restrictions are subject to entry into the register of town-planning conditions and restrictions. Access to the data of the register of townplanning conditions and restrictions should be provided free of charge by users through the officia website of the Department of Urban Planning and Architecture of the KSCA. However, the website (https://kga.gov.ua/reestr-mistobudivnikh-umov-ta-obmezhen) of the Register is not functioning properly yet.

\section{Submit a notice about the beginning of construction works}

Agency: Department of State Architectural and Construction Control of Kiev City Administration Improvement of the Construction Activity" of January 17, 2017. BuildCo must notify the Department for State Architectural Control Kiev City Council about the beginning of the construction works. BuildCo has the right to perform construction works the very next day after submitting a notice of the commencement of construction works to the GASK. 
The exact total price and other terms for connection the warehouse to water and sewage services should be stipulated in the agreement between the BuildCo as the customer and Kyivvodokanal Joint Stock Company as the supplier on the basis of project documentation elaborated for the purpose of connection. Therefore the cost provided above should be deemed as an average approximate cost.

$\rightarrow 7 \quad$ Pay contribution to the city social and engineering-transport infrastructure

Agency: Department of Economics and Investment of Kiev City Administration

Payment of the contribution to the city's social and engineering-transport infrastructure is regulated by Law of Ukraine "On town-planning regulation" and is clarified in Kiev by newly adopted Decision of Kyiv City Council No.411/1415 from 15.11.2016. Accordingly, the contribution shall be paid prior to putting the building into operation.

BuildCo shall submit a written application to Kyiv City Council with the following included:

- document on approval of design documentation;

- design documentation in part of technical-economic indexes and budget (if applicable);

- conclusion of state expertise of budget (if applicable);

- technical passport of warehouse:

According to the Decision, the value of the contribution is $4 \%$ of the construction budget starting from 1 January 2018. The contribution has been temporarily decreased to $3.2 \%$ for the period of 01.01.2019 -- 31.12.2019.

8 Prepare and submit declaration of readiness to operate the constructed warehouse to the State Inspection of Architectural and Building Control

Agency: Department of State Architectural and Construction Control of Kiev City Administration The procedure for obtaining permission to start the operation of a newly constructed building depends on the class of consequences of construction projects. The warehouse that BuildCo intends to build will fall into objects with minor consequences (CC1). However, such conclusions must be confirmed by the project organization. The assignment of a warehouse to objects of class $\mathrm{CC} 1$ assumes that its acceptance into operation is carried out by registration of the declaration of readiness of the object for operation submitted by the Department of State Architectural and Construction Control of Kiev (hereinafter referred to as the Department). BuildCo is responsible for completeness and reliability of the data specified in the submitted declaration. The Department verifies the completeness of the data specified in the declaration within ten working days from the date of receipt of the declaration and ensures that the information specified in the declaration is included in a single register of documents indicating the acceptance of the completed construction projects. The date of acceptance of the facility is the date of registration of the declaration

In detail, the procedure for accepting completed construction projects is described in the Law No. 3038-VI of Ukraine "On the Regulation of Urban Development Activity" dated 17.02.2011 and Resolution No. 461 of the Cabinet of Ministers of Ukraine dated 13.04.2011 on "The issues of commissioning completed construction projects."

Agency : Department of Urban Development and Architecture of Kiev City Administration Assignment of the postal address is carried out on the basis of the corresponding order of the Department of Urban Development and Architecture of Kiev City Administration. For the purpose of assigning a postal address to the warehouse, it is necessary to apply to the Urban Development and Architecture Department through the city licensing center (the Administrative Services Center) with the appropriate application, including, inter alia, a declaration on the readiness of the facility for operation, a certificate of payment of equity participation in the creation of a social and the engineering and transport infrastructure in Kiev, a copy of the technical passport of the warehouse and a copy of the executive (control and geodetic) survey.

The Urban Cadaster Department of the Urban Development and Architecture Department considers applications for assigning a postal address within fifteen working days and prepares a draft of an appropriate order of the Urban Planning and Architecture Department on assigning a postal address.

The address of the object is considered to be assigned from the moment the address is entered in the register. The address in the register of addresses is made by the Urban Cadaster Service of the Urban Planning and Architecture Department within three working days from the date of issuance of the order of the Urban Planning and Architecture Department about the assignment of the postal address. 
Agency: Department for Registration of Kiev City State Administration

The registration of the ownership of BuildCo is carried out by making a new record of the warehouse in the State Register of Rights. This procedure is regulated by the Law No. 1952-IV of Ukraine "On State Registration of Real Property Rights and Their Encumbrances" dated 01.07.2004, as well as the Resolution No. 1127 of the Cabinet of Ministers of Ukraine "On State Registration of Real Rights to Immovable Property and their Encumbrances" dated 25.12.2015. In particular, according to paragraph 41 of Resolution No. 1127, for the state registration of ownership of the constructed property, the applicant submits the following list of documents: 1) a document evidencing the acceptance into operation of the completed construction project; 2) technical passport for the immovable property;

3) a document confirming the assignment of the immovable property address.

The resolution also provides for the submission of documents to the state registering entity in electronic form, but in practice this norm does not work yet.

The ownership of the property is considered registered at the time of posting information about the ownership of the site on the Ministry of Justice web portal for access to the applicant. After the information is entered into the State Register of Rights, the state registrar, with the help of software for maintaining the specified register, generates an extract from it on state registration of rights, posted on the Ministry's web portal for access to the applicant for the purpose of viewing, downloading and printing.

An extract from the State Register of Rights on the state registration of rights can be provided by the state registrar in paper form at the request of the applicant, by printing with the help of software for maintaining the State Register of Rights on sheets of A4 paper without the use of special forms, with the signature and seal of the state registrar.

There are several options for the duration of the procedure of registration envisaged by the law on State

Registration of Real Property Rights and Their Encumbrances (articles 19 and 34). The payment for the procedure is stipulated in minimum living wages and depends on the duration: faster procedure requires bigger payment. The following options are available:

5 working days - 0.1 minimum living wage

2 working days -1 minimum living wage

1 working day - 2 minimum living wage

2 hours -5 minimum living wage

\footnotetext{
$\rightarrow$ Takes place simultaneously with previous procedure.
} 
Details - Dealing with Construction Permits in Ukraine - Measure of Quality

Answer

Score

Building quality control index (0-15)

12.0

Quality of building regulations index (0-2)

2.0

How accessible are building laws and regulations in your economy? (0-1)

Available online; Free $\quad 1.0$

of charge.

List of required documents; Fees to

be paid; Required

preapprovals.

Quality control before construction index (0-1)

Which third-party entities are required by law to verify that the building plans are in compliance with existing building regulations? (0-1)

By law, there is no need to verify plans compliance.

\section{Quality control during construction index (0-3)}

What types of inspections (if any) are required by law to be carried out during construction? (0-2)

Inspections by in-

house engineer;

Inspections at various

phases.

Do legally mandated inspections occur in practice during construction? (0-1)

Mandatory

inspections are

always done in

practice.

\section{Quality control after construction index (0-3)}

3.0

Is there a final inspection required by law to verify that the building was built in accordance with the approved plans and regulations? $(0-2)$

Yes, in-house engineer submits report for final inspection.

Do legally mandated final inspections occur in practice? (0-1)

Final inspection

always occurs in practice.

Liability and insurance regimes index (0-2)

Which parties (if any) are held liable by law for structural flaws or problems in the building once it is in use (Latent Defect Liability or Decennial Liability)? (0-1)

Architect or engineer; $\quad 1.0$

Construction

company.

Which parties (if any) are required by law to obtain an insurance policy to cover possible structural flaws or problems in the building once it is in use (Latent Defect Liability Insurance or Decennial Insurance)? (0-1)

No party is required

by law to obtain insurance.

\section{Professional certifications index (0-4)}

What are the qualification requirements for the professional responsible for verifying that the architectural plans or drawings are in compliance with existing building regulations? (0-2)

Minimum number of years of experience; University degree in architecture or engineering; Passing a certification exam.

What are the qualification requirements for the professional who supervises the construction on the ground? (02)

Minimum number of years of experience; University degree in engineering, construction or construction management; Passing a certification exam. 


\section{Getting Electricity}

This topic measures the procedures, time and cost required for a business to obtain a permanent electricity connection for a newly constructed warehouse. Additionally, the reliability of supply and transparency of tariffs index measures reliability of supply, transparency of tariffs and the price of electricity. The most recent round of data collection for the project was completed in May 2019. See the methodology for more information.

\section{What the indicators measure}

\section{Procedures to obtain an electricity connection (number)}

- Submitting all relevant documents and obtaining all necessary clearances and permits

- Completing all required notifications and receiving all necessary inspections

- Obtaining external installation works and possibly purchasing material for these works

- Concluding any necessary supply contract and obtaining final supply

\section{Time required to complete each procedure (calendar days)}

- Is at least 1 calendar day

- Each procedure starts on a separate day

- Does not include time spent gathering information

- Reflects the time spent in practice, with little follow-up and no prior contact with officials

\section{Cost required to complete each procedure (\% of income per} capita)

- Official costs only, no bribes

- Value added tax excluded

The reliability of supply and transparency of tariffs index (0-8)

- Duration and frequency of power outages (0-3)

- Tools to monitor power outages (0-1)

- Tools to restore power supply (0-1)

- Regulatory monitoring of utilities' performance (0-1)

- Financial deterrents limiting outages (0-1)

- Transparency and accessibility of tariffs (0-1)

\section{Price of electricity (cents per kilowatt-hour)*}

- Price based on monthly bill for commercial warehouse in case study

*Note: Doing Business measures the price of electricity, but it is not included in the ease of doing business score nor in the ranking on the ease of getting electricity.

\section{Case study assumptions}

To make the data comparable across economies, several assumptions about the warehouse, the electricity connection and the monthly consumption are used.

\section{The warehouse:}

- Is owned by a local entrepreneur and is used for storage of goods.

- Is located in the economy's largest business city. For 11 economies the data are also collected for the second largest business city.

- Is located in an area where similar warehouses are typically located and is in an area with no physical constraints. For example, the property is not near a railway.

- Is a new construction and is being connected to electricity for the first time.

- Has two stories with a total surface area of approximately 1,300.6 square meters ( 14,000 square feet). The plot of land on which it is built is 929 square meters (10,000 square feet).

\section{The electricity connection:}

- Is a permanent one with a three-phase, four-wire $Y$ connection with a subscribed capacity of 140kilo-volt-ampere (kVA) with a power factor of 1 , when $1 \mathrm{kVA}=1$ kilowatt $(\mathrm{kW})$.

- Has a length of 150 meters. The connection is to either the low- or medium-voltage distribution network and is either overhead or underground, whichever is more common in the area where the warehouse is located and requires works that involve the crossing of a 10-meter road (such as by excavation or overhead lines) but are all carried out on public land. There is no crossing of other owners' private property because the warehouse has access to a road.

- Does not require work to install the internal wiring of the warehouse. This has already been completed up to and including the customer's service panel or switchboard and the meter base.

\section{The monthly consumption:}

- It is assumed that the warehouse operates 30 days a month from 9:00 a.m. to 5:00 p.m. (8 hours a day), with equipment utilized at $80 \%$ of capacity on average and that there are no electricity cuts (assumed for simplicity reasons) and the monthly energy consumption is 26,880 kilowatt-hours (kWh); hourly consumption is $112 \mathrm{kWh}$.

- If multiple electricity suppliers exist, the warehouse is served by the cheapest supplier.

- Tariffs effective in January of the current year are used for calculation of the price of electricity for the warehouse. Although January has 31 days, for calculation purposes only 30 days are used. 


\section{Getting Electricity - Ukraine}

\section{Standardized Connection}

Name of utility

Price of electricity (US cents per kWh)

6.4

City Covered

Kyiv

Indicator

Ukraine

$\begin{array}{lll}\begin{array}{l}\text { Europe \& Central } \\ \text { Asia }\end{array} & \begin{array}{l}\text { OECD high } \\ \text { income }\end{array} & \begin{array}{l}\text { Best Regulatory } \\ \text { Performance }\end{array}\end{array}$

\begin{tabular}{|c|c|c|c|c|}
\hline Procedures (number) & 5 & 5.1 & 4.4 & 3 (28 Economies) \\
\hline Time (days) & 267 & 99.6 & 74.8 & 18 (3 Economies) \\
\hline Cost ( $\%$ of income per capita) & 353.2 & 271.9 & 61.0 & 0.0 (3 Economies) \\
\hline Reliability of supply and transparency of tariff index $(0-8)$ & 7 & 6.2 & 7.4 & 8 (26 Economies) \\
\hline
\end{tabular}

Figure - Getting Electricity in Ukraine - Score

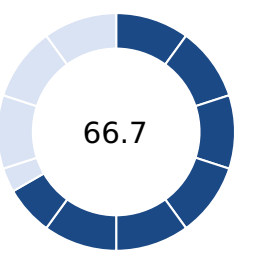

Procedures
0.0

Time

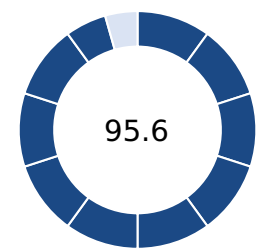

Cost

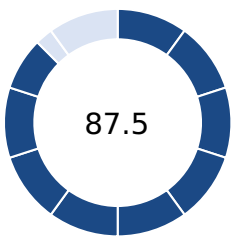

Reliability of supply and transparency of tariff index

Figure - Getting Electricity in Ukraine and comparator economies - Ranking and Score

\section{DB 2020 Getting Electricity Score}

$\mathbf{0}$

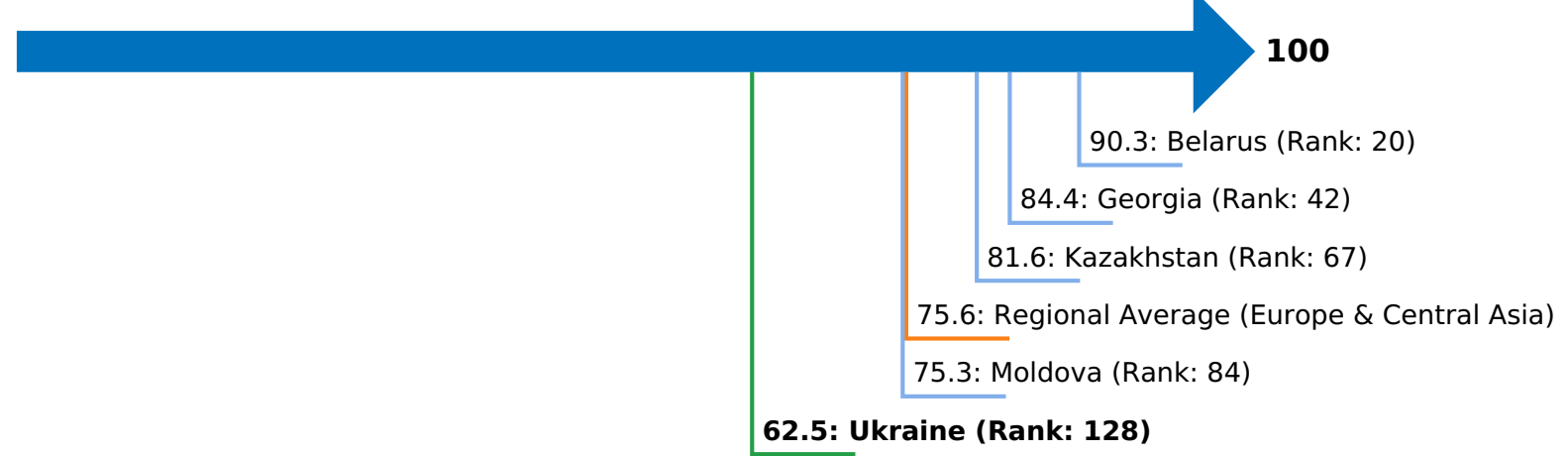

Note: The ranking of economies on the ease of getting electricity is determined by sorting their scores for getting electricity. These scores are the simple average of the scores for all the component indicators except the price of electricity.

\section{Figure - Getting Electricity in Ukraine - Procedure, Time and Cost}

- Time (days) $\quad$ - Cost (\% of income per capita)

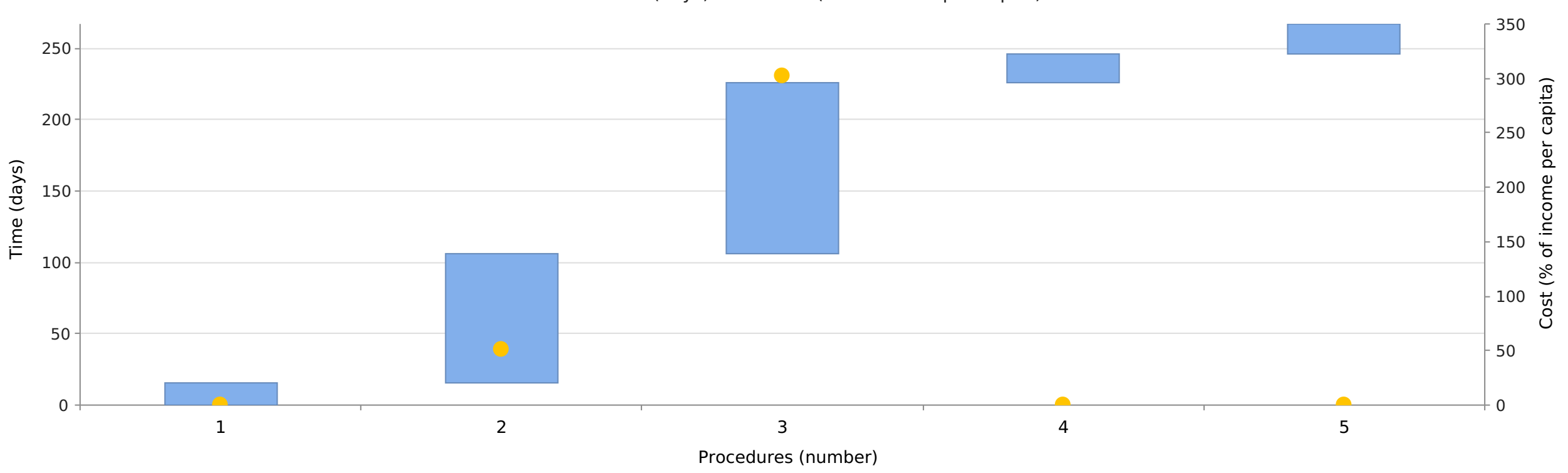

*This symbol is shown beside procedure numbers that take place simultaneously with the previous procedure. 
reflected here, see the summary below.

Figure - Getting Electricity in Ukraine and comparator economies - Measure of Quality

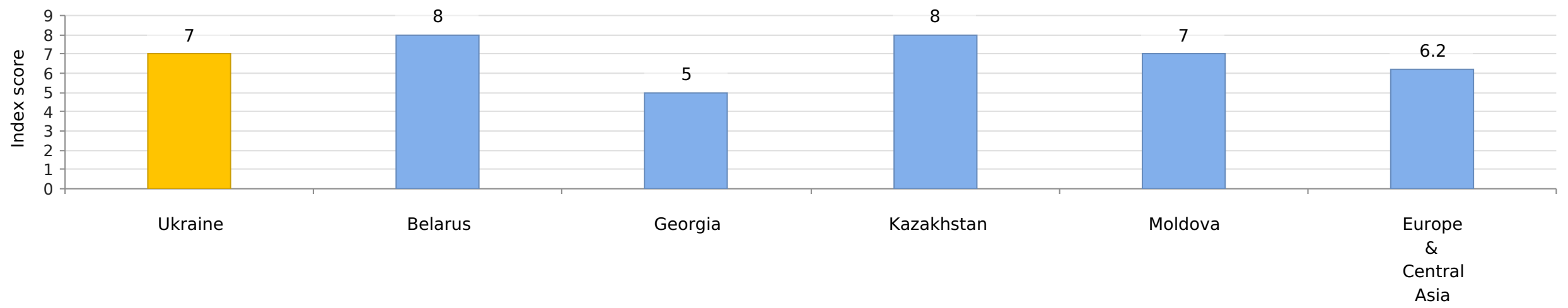




\section{Details - Getting Electricity in Ukraine - Procedure, Time and Cost}

\section{No. Procedures}

\section{Submit application to DTEK Kyiv Electric Networks and await technical conditions} Agency : DTEK Kyiv Electric Networks

The customer submits to DTEK Kyiv Electric Networks an application for an electricity connection. Attached to the application the customer has to submit a number of documents: 1 ) the documents proving the ownership of the object; 2 ) the plan with the location of the object indicated; 3)the document proving the right of the person to sign the agreement on behalf of the company; 4) technical and financial feasibility sudy (if available); 5) copy of the certificate of a VAT payer (or a payer of a fixed tax). If the application includes all the necessary documents. In the application, the customer may also indicate its will to design the connection indpendently. Then, the technical conditions must provide the necessary basic data for such a design. Based on this information, DTEK issues a technical conditions.

\section{Time to Complete}

Associated Costs
UAH 0
16 calendar days

\section{Await project design of external connection by private firm and its approval}

Agency : Project design firm

In most cases customers choose to design the connection independently. DTEK is obliged to provide all the information necessary for designing the project upon the customer's request. The project must set the connection points. This project then must be approved by DTEK, (and if there is a need to get an approval of other operators). In case the project design must be improved, the customer has 30 days to do that.

\section{Await completion of external connection works}

Agency : DTEK Kyiv Electric Networks

Once the external connection design is ready and approved, the customer needs to make the payments for the connection.

DTEK Kyiv Electric Networks will select a contractor on a tender base who will under utility's supervision obtain the necessary permits, including excavation permit, and carry out the works.

\section{Conclude supply contract with Kyiv Energy Services LLC}

Agency: Kyiv Energy Services LLC

Before turning on the power, the customer has to first conclude a supply contract with Kyiv Energy

Services LLC. The supply contract can be concluded only after all the inspections are completed.

The documents for the supply contract can be presented in the office or sent by mail. It is required to submit a number of documents regarding internal wiring including a Technical Report of the tests of the internal wiring which should be completed after the internal wiring was finished by an electrician.

\section{$5 \quad$ Request and receive turn-on of power by DTEK Kyiv Electric Networks}

Once supply agreement is concluded, the customer can visit the dispatcher department of DTEK Kyiv Electric Networks and request power turn on. The dispatcher department processes the order which permits it to turn off the $10 \mathrm{kV}$ cable line, do the testing of the high voltage cable and finally turn on the electricity for the substation.

$\rightarrow$ Takes place simultaneously with previous procedure. 
Details - Getting Electricity in Ukraine - Measure of Quality

Answer

Reliability of supply and transparency of tariff index (0-8)

Total duration and frequency of outages per customer a year (0-3)

System average interruption duration index (SAIDI)

System average interruption frequency index (SAIFI)

1.6

What is the minimum outage time (in minutes) that the utility considers for the calculation of SAIDI/SAIFI

3.0

Mechanisms for monitoring outages (0-1)

Does the distribution utility use automated tools to monitor outages?

Yes

Mechanisms for restoring service (0-1)

Does the distribution utility use automated tools to restore service?

Yes

Regulatory monitoring (0-1)

1

Does a regulator-that is, an entity separate from the utility-monitor the utility's performance on reliability of supply?

Yes

Financial deterrents aimed at limiting outages (0-1)

Does the utility either pay compensation to customers or face fines by the regulator (or both) if outages exceed a certain cap?

Yes

Communication of tariffs and tariff changes (0-1)

Are effective tariffs available online?

Yes

Link to the website, if available online

https://dtek-kem.com.ua www.nerc.gov.ua

Are customers notified of a change in tariff ahead of the billing cycle?

Yes

Note:

If the duration and frequency of outages is 100 or less, the economy is eligible to score on the Reliability of supply and transparency of tariff index

If the duration and frequency of outages is not available, or is over 100, the economy is not eligible to score on the index.

If the minimum outage time considered for SAIDI/SAIFI is over 5 minutes, the economy is not eligible to score on the index. 


\section{Registering Property}

This topic examines the steps, time and cost involved in registering property, assuming a standardized case of an entrepreneur who wants to purchase land and a building that is already registered and free of title dispute. In addition, the topic also measures the quality of the land administration system in each economy. The quality of land administration index has five dimensions: reliability of infrastructure, transparency of information, geographic coverage, land dispute resolution, and equal access to property rights. The most recent round of data collection for the project was completed in May 2019. See the methodology for more information.

\section{What the indicators measure}

\section{Procedures to legally transfer title on immovable property} (number)

- Preregistration procedures (for example, checking for liens, notarizing sales agreement, paying property transfer taxes)

- Registration procedures in the economy's largest business city.

- Postregistration procedures (for example, filling title with municipality)

\section{Time required to complete each procedure (calendar days)}

- Does not include time spent gathering information

- Each procedure starts on a separate day - though procedures that can be fully completed online are an exception to this rule

- Procedure is considered completed once final document is received

- No prior contact with officials

\section{Cost required to complete each procedure (\% of property} value)

- Official costs only (such as administrative fees, duties and taxes).

- Value Added Tax, Capital Gains Tax and illicit payments are excluded

\section{Quality of land administration index (0-30)}

- Reliability of infrastructure index (0-8)

- Transparency of information index (0-6)

- Geographic coverage index (0-8)

- Land dispute resolution index (0-8)

- Equal access to property rights index (-2-0)

\section{Case study assumptions}

To make the data comparable across economies, several assumptions about the parties to the transaction, the property and the procedures are used.

\section{The parties (buyer and seller):}

- Are limited liability companies (or the legal equivalent).

- Are located in the periurban (that is, on the outskirts of the city but still within its official limits) area of the economy's largest business city. For 11 economies the data are also collected for the second largest business city.

- Are $100 \%$ domestically and privately owned.

- Perform general commercial activities.

\section{The property (fully owned by the seller):}

- Has a value of 50 times income per capita, which equals the sale price.

- Is fully owned by the seller.

- Has no mortgages attached and has been under the same ownership for the past 10 years. - Is registered in the land registry or cadastre, or both, and is free of title disputes.

- Is located in a periurban commercial zone (that is, on the outskirts of the city but still within its official limits), and no rezoning is required.

- Consists of land and a building. The land area is 557.4 square meters (6,000 square feet). A twostory warehouse of 929 square meters (10,000 square feet) is located on the land. The warehouse is 10 years old, is in good condition, has no heating system and complies with all safety standards, building codes and legal requirements. The property, consisting of land and building, will be transferred in its entirety.

- Will not be subject to renovations or additional construction following the purchase.

- Has no trees, natural water sources, natural reserves or historical monuments of any kind. - Will not be used for special purposes, and no special permits, such as for residential use, industrial plants, waste storage or certain types of agricultural activities, are required. - Has no occupants, and no other party holds a legal interest in it. 


\section{Registering Property - Ukraine}

\begin{tabular}{|c|c|c|c|c|}
\hline Indicator & Ukraine & $\begin{array}{l}\text { Europe \& Central } \\
\text { Asia }\end{array}$ & $\begin{array}{l}\text { OECD high } \\
\text { income }\end{array}$ & $\begin{array}{l}\text { Best Regulatory } \\
\text { Performance }\end{array}$ \\
\hline Procedures (number) & 7 & 5.5 & 4.7 & 1 (5 Economies) \\
\hline Time (days) & 15 & 20.8 & 23.6 & 1 (2 Economies) \\
\hline Cost ( $\%$ of property value) & 1.7 & 2.7 & 4.2 & 0.0 (Saudi Arabia) \\
\hline Quality of the land administration index (0-30) & 16.0 & 20.4 & 23.2 & None in 2018/19 \\
\hline
\end{tabular}

Figure - Registering Property in Ukraine - Score

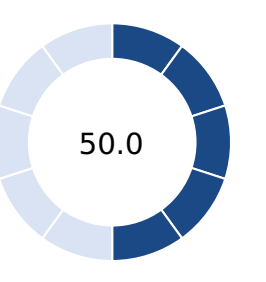

Procedures

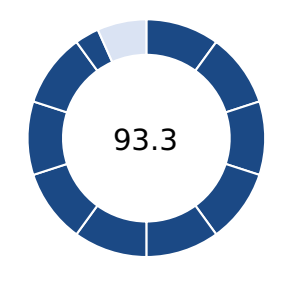

Time

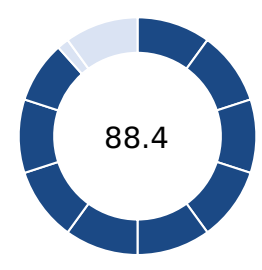

Cost

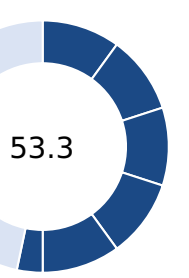

Quality of the land administration index

Figure - Registering Property in Ukraine and comparator economies - Ranking and Score

DB 2020 Registering Property Score

$\mathbf{0}$

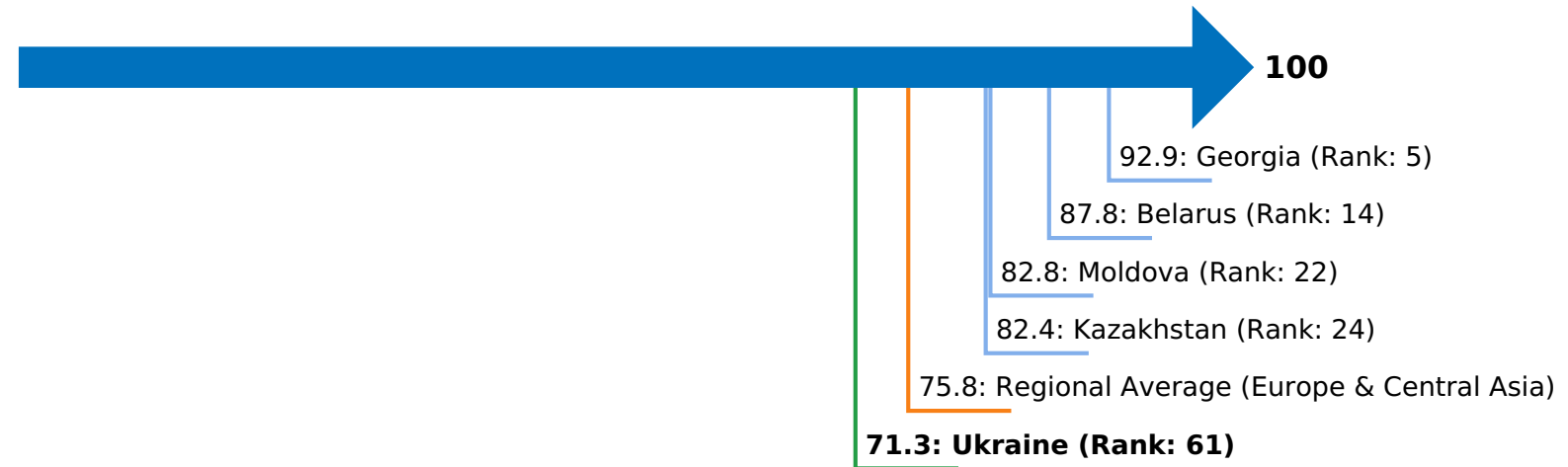

Note: The ranking of economies on the ease of registering property is determined by sorting their scores for registering property. These scores are the simple average of the scores for each of the component indicators. 
Figure - Registering Property in Ukraine - Procedure, Time and Cost

- Time (days) $\quad$ Cost ( $\%$ of property value)

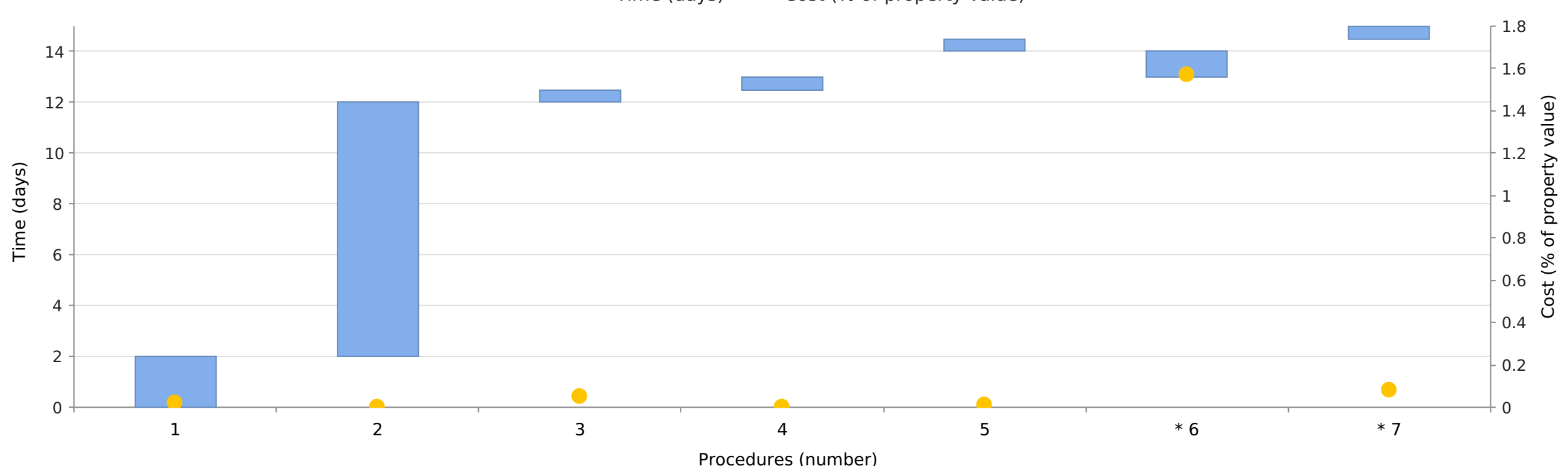

*This symbol is shown beside procedure numbers that take place simultaneously with the previous procedure.

Note: Online procedures account for 0.5 days in the total time calculation. For economies that have a different procedure list for men and women, the graph shows the time for women. For more information on methodology, see the Doing Business website (http://doingbusiness.org/en/methodology). For details on the procedures reflected here, see the summary below. 
Figure - Registering Property in Ukraine and comparator economies - Measure of Quality

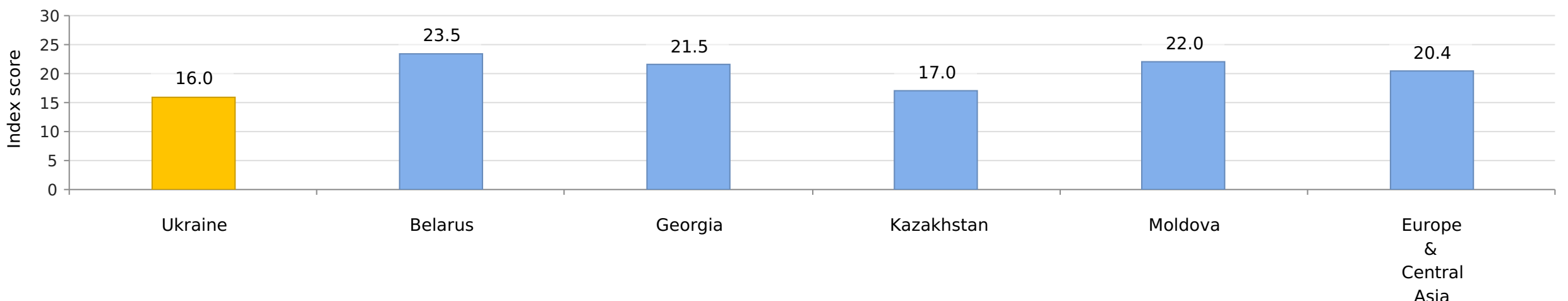

Details - Registering Property in Ukraine - Procedure, Time and Cost

\section{No. Procedures}

Time to Complete

2 days

Assess the price of the land

Agency: Legal entities which are licenced by the State Center of the Land Cadastre

The document on expert evaluation of the price of immovable property can be provided by experts certified by the State Property Fund of Ukraine. Such experts have access to evaluation software and record the price at the State Property Fund. Expert evaluation of the price of immovable property is required for tax assessment purposes.

\section{Associated Costs}

UAH 1,000; (Average price charged by experts certified by the State Property Fund of Ukraine to assess the price of land)

\section{Obtain the extract from the State Center of the Land Cadastre}

Agency: State Service for Geodesy, Cartography and Cadastre - (Derzhgeocadastre)

The extract from State Land Cadastre contains full information about the land plot (owner, location, use restrictions, encumbrances etc). The notary may not attest the agreement without such extract. The procedure is governed by Article 38 of the Law 'On State Land Cadastre' and Paragraphs 162 - 186 of the CMU Resolution No 1051. While the CMU Resolution No 1051 allows the notary to obtain the extract electronically, this option is not available for technical reasons.

The Seller shall submit the following documents to obtain the extract:

- application in accordance with established form;

- document confirming payment of fee for issuance of the extract;

- document confirming powers of the person to request and obtain the extract.

In addition to the above documents, the Seller shall present original document confirming ownership rights to the land plot (e.g. a state act of ownership rights) and personal identification document. The extract is valid for 3 months.

From 31 August 2015 notary has on-line access to the State Land Cadastre and includes cost of obtaining the extract from the State Land Cadastre into the notary fees.

In addition, the extract from the State Center of the Land Cadastre can be also provided through Administration Service Center. In this case an applicant may order the document (excerpt from the State Land Cadastre about a land plot) online at http://map.land.gov.ua, but will have to visit the Administration Service Center in order to receive the document.
AH 100; (5\% of the living wage of UAH 1921, rounded to the nearest 10 UAH.) 
3 Notary registers ownership rights for seller in the new State Register of Property Rights to Immovable Property

Agency: Notary

From January 01, 2013, a new State Register of Property Rights to Immovable Property (“Register of Property Rights") has been launched. Unlike the State Land Cadastre, which automatically absorbed information about all existing land plots from the (no longer active) State Register of Lands, the Register of Property Rights does not contain information about the ownership rights to immovable property which have been registered before January 01 , 2013. For this reason, prior to execution of the Property sale and purchase agreement, the Seller has to register ownership rights to the Property in the new Register of Property Rights.

Starting from January 01, 2016 registration of ownership rights for seller in the new State Register of Property Rights to Immovable Property is not mandatory. The notary may skip this step and proceed directly with the registration of the ownership right of the buyer although the property to be acquired has not been registered with the Register of Property Rights. However, the procedure is still widely implemented in practice.

Procedures 3-7 are being completed simultaneously at the notary's office.

Registration of Seller's ownership rights to the Property is performed by the notary attesting the sale and purchase agreement. The

Seller shall provide to the notary:

- ownership documents to the Property;

- application in accordance with established form;

- documents confirming payment of registration fees.

The notary: (1) checks the Seller's ownership documents; (2) records Seller's ownership rights in the Register of Property Rights;

and (3) issues an extract from the Register of Property Rights confirming Seller's ownership rights to the Property. "
Less than one day, online
UAH 1,880; (UAH 1500 notary fee

UAH 190 for the initial registration of the land in the new registry of ownership rights UAH 190 for the initial registration of the warehouse)
Obtain the extract from the State Register of Encumbrances over movable property

Agency: Notary

The notary will verify through this procedure that the tax authorities have not registered a security interest over the real property. Since January 2013, the notaries can obtain this information online.
Less than one day, online

Less than one day, online
UAH 80; (4\% of living wage of UAH 1921, rounded to the nearest 10 $\mathrm{UAH}$.

UAH 240; (UAH 80 for the Seller's LLC

UAH 80 for checking against encumbrances on land

UAH 80 for checking against encumbrances on warehouse

Total: UAH 240

( $4 \%$ of living wage of UAH 1921 , rounded to the nearest $10 \mathrm{UAH}$.$) )$

(1) State Register of Mortgages

(2) State Register of Immovable Property Alienation Bans; and

(3) State Register of Encumbrances over Movable Property (in respect of tax liens) - are inactive. These registers serve only as a source of information for the notary who transfers the relevant encumbrances from these registers to the Register of Property Rights upon first-time registration of ownership rights to immovable property in the Register of Property Rights. Therefore, to verify encumbrances on the property ownership rights to which have been registered in the Register of Property Rights, the notary will search only in this register. This procedure takes one day and is performed on the same day on which the Property sale and purchase agreement is executed, prior to the execution of the agreement. 
The sale purchase agreement of the building is notarized by a private or public notary. Notary's fees are agreed among parties. There could be one single agreement underpinning both sale of building and sale of land or be two separate agreements: the sale of building (warehouse) and the sale of land parcel. Parties can prepare the sale agreements by themselves before notarization, but usually the notary prefers to use his standard proforma.

State Duty (fee) is paid to the notary and equals $1 \%$ of the transactional value of the building. The buyer of the building will also pay a special assessment in the amount of $1 \%$ of building's transactional value to the State Pension Fund. The buyer can make the payment to the State Pension Fund prior to the notarization of building sale agreement or provide the notary with the money to make such payment.

The documentation shall include:

- Ownership documents

- Founding documents of the company

- Decision with respect to the sale of the building (if necessary)

- Extract from the State Land Cadastre,

- Extracts from the Unified State Registry of Legal Persons and Physical Persons - Entrepreneurs (documents - copy of the passport and application, issuing authority - any State District Administration in the City (but it is recommended to obtain it in the administration in which respective legal person was registered))

- Act of evaluation of parcel of land, powers of attorney (if necessary)

- Notary certifies agreement, makes inscription on the State Certificate on Land Ownership as to the transference of title over parcel of land to new owner, registers information as to the transaction in the Unified State Registry of Transactions and issues an extract from this registry on above mentioned transaction.

\section{$\rightrightarrows 7 \quad$ Notary registers Buyer's ownership rights on the property in the Register of Property}

\section{Rights}

Agency: Notary

From January 01,2013 , the registration of ownership rights to immovable property (other than newly constructed building/newly allotted land plot in some other cases) is performed by notaries attesting the sale and purchase agreement (Articles 3.5, 9 of the Law of Ukraine "On State Registration of Property Rights to Immovable Property and Their Encumbrances").

Following notarial attestation of the Property sale and purchase agreement, the notary shall register Buyer's ownership rights to the Property in the Register of Property Rights. The procedure of registration is governed by Articles 15-24 of the Law of Ukraine "On State Registration of Property Rights to Immovable Property and Their Encumbrances" No 1952-IV of July 01, 2004, as restated and amended, and the Resolution of Cabinet of Ministers of Ukraine No 703 dated June 22, 2011, as amended ("CMU Resolution No 703"). The registration is performed by the notary based on the Buyer's application (in accordance with established form) and the Property sale and

Less than one day, online issues an extract from the Register of Property Rights for the Buyer. 
Details - Registering Property in Ukraine - Measure of Quality

Answer

Score

Quality of the land administration index (0-30)

Reliability of infrastructure index (0-8)

5.0

Type of land registration system in the economy:

Title Registration

System

What is the institution in charge of immovable property registration?

State Registry on

Property Rights under

the Ministry of Justice

In what format land title certificates are kept at the immovable property registry of the largest business city of the Computer/Scanned economy -in a paper format or in a computerized format (scanned or fully digital)?

Is there a comprehensive and functional electronic database for checking for encumbrances (liens, mortgages, Yes restrictions and the like)?

Institution in charge of the plans showing legal boundaries in the largest business city:

State Enterprise

"Centre for the State

Land Cadastre"

In what format cadastral plans are kept at the mapping agency of the largest business city of the economy-in a Computer/Fully digital 2.0 paper format or in a computerized format (scanned or fully digital)?

Is there an electronic database for recording boundaries, checking plans and providing cadastral information (geographic information system)?

Is the information recorded by the immovable property registration agency and the cadastral or mapping agency Separate databases kept in a single database, in different but linked databases or in separate databases?

Do the immovable property registration agency and cadastral or mapping agency use the same identification number for properties?

\section{Transparency of information index (0-6)}

Yes

Who is able to obtain information on land ownership at the agency in charge of immovable property registration in the largest business city?

Only intermediaries (notaries, lawyers, etc.)

Is the list of documents that are required to complete any type of property transaction made publicly availableand if so, how?

Link for online access:

Yes, online

http://zakon3.rada.go v.ua/laws/show/1127 2015-\%D0\%BF

Is the applicable fee schedule for any type of property transaction at the agency in charge of immovable property registration in the largest business city made publicly available-and if so, how?

Link for online access:

Yes, online

http://terjust.gov.ua/2

019/01/увага-з-01-

січня-2019-року

змінилися-ставки

https://vnpu.kiev.ua/?

$p=3333$

Does the agency in charge of immovable property registration agency formally commit to deliver a legally

binding document that proves property ownership within a specific timeframe -and if so, how does it

Yes, online

0.5

communicate the service standard?

Link for online access:

http://ddr.minjust.gov.

ua/uk/4424bbf47abcd

$8 a 3 a 6 f 65 c a 7 a 025643$

5/normatyvnopravova

_baza/

Is there a specific and independent mechanism for filing complaints about a problem that occurred at the agency in charge of immovable property registration?

Contact information: 
Who is able to consult maps of land plots in the largest business city?

Link for online access:

Does the cadastral/mapping agency formally specifies the timeframe to deliver an updated cadastral plan-and if so, how does it communicate the service standard?

Link for online access:

Is there a specific and independent mechanism for filing complaints about a problem that occurred at the cadastral or mapping agency?

\section{Contact information:}

\section{Geographic coverage index (0-8)}

Are all privately held land plots in the largest business city formally registered at the immovable property registry?

Are all privately held land plots in the economy formally registered at the immovable property registry?

No

Are all privately held land plots in the largest business city mapped?

No

No

No 0.0

\section{Land dispute resolution index (0-8)}

Does the law require that all property sale transactions be registered at the immovable property registry to make them opposable to third parties?

Legal basis:

Is the system of immovable property registration subject to a state or private guarantee?

Type of guarantee:

Legal basis:
Yes

Pusuant to the part 4

of Art. 334 of the Civil

Code of Ukraine if the

contract on the

property alienation is

subject to state

registration, the

beneficiary shall

aquire the ownership

right since the

moment of such

registration. Art. 3 of

the Law of Ukraine

"On State

Registration of

Proprietary Rights to

Real Estate and Their

Encumbrances" the

rights to immovable

property and

encumbrances that

are subject subject to

the state registration

under this Act, shall

arise from the

moment of their

registration.

\section{5}

0.0

0.0

0.0

\section{5}

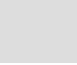


Is there a is a specific, out-of-court compensation mechanism to cover for losses incurred by parties who engaged in good faith in a property transaction based on erroneous information certified by the immovable property registry?

Legal basis:

Does the legal system require a control of legality of the documents necessary for a property transaction (e.g., Yes checking the compliance of contracts with requirements of the law)?

If yes, who is responsible for checking the legality of the documents?

Notary;

Does the legal system require verification of the identity of the parties to a property transaction?

Yes

0.5

If yes, who is responsible for verifying the identity of the parties?

Notary;

Is there a national database to verify the accuracy of government issued identity documents?

Yes

What is the Court of first instance in charge of a case involving a standard land dispute between two local businesses over tenure rights for a property worth 50 times gross national income (GNI) per capita and located in the largest business city?

The Commercial

(Economic) Court of

Kyiv

How long does it take on average to obtain a decision from the first-instance court for such a case (without

Less than a year appeal)?

Are there publicly available statistics on the number of land disputes at the economy level in the first instance

Yes court?

Number of land disputes in the economy in 2018 :

4,570 cases out of

109,220

Equal access to property rights index (-2-0)

Do unmarried men and unmarried women have equal ownership rights to property? 


\section{Getting Credit}

This topic explores two sets of issues-the strength of credit reporting systems and the effectiveness of collateral and bankruptcy laws in facilitating lending. The most recent round of data collection for the project was completed in May 2019. See the methodology for more information.

\section{What the indicators measure}

\section{Strength of legal rights index (0-12)}

- Rights of borrowers and lenders through collateral laws (0-10)

- Protection of secured creditors' rights through bankruptcy laws $(0-2)$

\section{Depth of credit information index (0-8)}

- Scope and accessibility of credit information distributed by credit bureaus and credit registries (0-8)

\section{Credit bureau coverage (\% of adults)}

- Number of individuals and firms listed in largest credit bureau as a percentage of adult population

\section{Credit registry coverage (\% of adults)}

- Number of individuals and firms listed in credit registry as a percentage of adult population

\section{Case study assumptions}

Doing Business assesses the sharing of credit information and the legal rights of borrowers and lenders with respect to secured transactions through 2 sets of indicators. The depth of credit information index measures rules and practices affecting the coverage, scope and accessibility of credit information available through a credit registry or a credit bureau. The strength of legal rights index measures the degree to which collateral and bankruptcy laws protect the rights of borrowers and lenders and thus facilitate lending. For each economy it is first determined whether a unitary secured transactions system exists. Then two case scenarios, case A and case B, are used to determine how a nonpossessory security interest is created, publicized and enforced according to the law. Special emphasis is given to how the collateral registry operates (if registration of security interests is possible). The case scenarios involve a secured borrower, company $A B C$, and a secured lender, BizBank.

In some economies the legal framework for secured transactions will allow only case A or case B (not both) to apply. Both cases examine the same set of legal provisions relating to the use of movable collateral.

\section{Several assumptions about the secured borrower $(A B C)$ and lender (BizBank) are used:}

- $A B C$ is a domestic limited liability company (or its legal equivalent)

- $A B C$ has up to 50 employees.

- $A B C$ has its headquarters and only base of operations in the economy's largest business city. For 11 economies the data are also collected for the second largest business city.

- Both ABC and BizBank are 100\% domestically owned.

The case scenarios also involve assumptions. In case A, as collateral for the loan, ABC grants BizBank a nonpossessory security interest in one category of movable assets, for example, its machinery or its inventory. ABC wants to keep both possession and ownership of the collateral. In economies where the law does not allow nonpossessory security interests in movable property, $A B C$ and BizBank use a fiduciary transfer-of-title arrangement (or a similar substitute for nonpossessory security interests).

In case $B, A B C$ grants BizBank a business charge, enterprise charge, floating charge or any charge that gives BizBank a security interest over $A B C$ 's combined movable assets (or as much of $A B C$ 's movable assets as possible). ABC keeps ownership and possession of the assets. 


\section{Getting Credit - Ukraine}

\begin{tabular}{|c|c|c|c|c|}
\hline Indicator & Ukraine & $\begin{array}{l}\text { Europe \& Central } \\
\text { Asia }\end{array}$ & $\begin{array}{l}\text { OECD high } \\
\text { income }\end{array}$ & $\begin{array}{l}\text { Best Regulatory } \\
\text { Performance }\end{array}$ \\
\hline Strength of legal rights index $(0-12)$ & 8 & 7.8 & 6.1 & 12 (5 Economies) \\
\hline Depth of credit information index $(0-8)$ & 7 & 6.7 & 6.8 & 8 (53 Economies) \\
\hline Credit registry coverage ( $\%$ of adults) & 2.4 & 24.0 & 24.4 & 100.0 (2 Economies) \\
\hline Credit bureau coverage ( $\%$ of adults) & 56.9 & 41.7 & 66.7 & 100.0 (14 Economies) \\
\hline
\end{tabular}

Figure - Getting Credit in Ukraine - Score

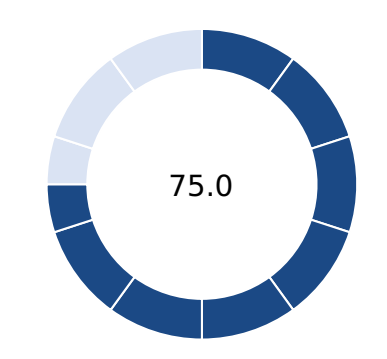

Score - Getting Credit

Figure - Getting Credit in Ukraine and comparator economies - Ranking and Score

DB 2020 Getting Credit Score

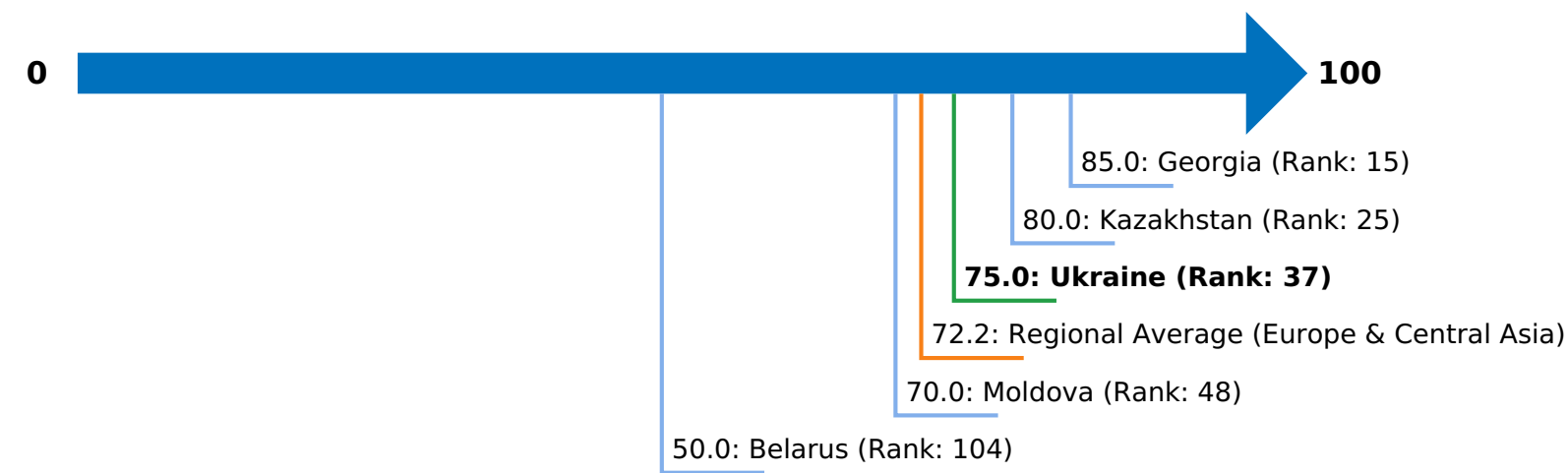

Note: The ranking of economies on the ease of getting credit is determined by sorting their scores for getting credit. These scores are the sum of the scores for the strength of legal rights index and the depth of credit information index. 
Figure - Legal Rights in Ukraine and comparator economies

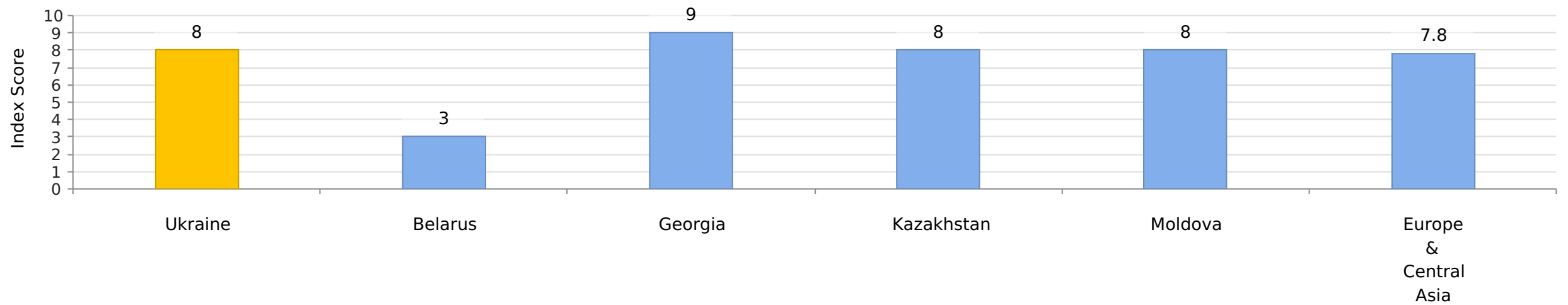




\section{Details - Legal Rights in Ukraine}

Strength of legal rights index (0-12)

Does an integrated or unified legal framework for secured transactions that extends to the creation, publicity and enforcement of functional equivalents No to security interests in movable assets exist in the economy?

Does the law allow businesses to grant a non possessory security right in a single category of movable assets, without requiring a specific description $\quad$ Yes of collateral?

Does the law allow businesses to grant a non possessory security right in substantially all of its assets, without requiring a specific description of collateral?

May a security right extend to future or after-acquired assets, and does it extend automatically to the products, proceeds and replacements of the original assets?

Is a general description of debts and obligations permitted in collateral agreements; can all types of debts and obligations be secured between parties; $\quad$ Yes and can the collateral agreement include a maximum amount for which the assets are encumbered?

Is a collateral registry in operation for both incorporated and non-incorporated entities, that is unified geographically and by asset type, with an electronic database indexed by debtor's name?

Does a notice-based collateral registry exist in which all functional equivalents can be registered?

Does a modern collateral registry exist in which registrations, amendments, cancellations and searches can be performed online by any interested third No party?

Are secured creditors paid first (i.e. before tax claims and employee claims) when a debtor defaults outside an insolvency procedure?

Are secured creditors subject to an automatic stay on enforcement when a debtor enters a court-supervised reorganization procedure? Does the law $\quad$ No protect secured creditors' rights by providing clear grounds for relief from the stay and sets a time limit for it?

Does the law allow parties to agree on out of court enforcement at the time a security interest is created? Does the law allow the secured creditor to sell Yes the collateral through public auction or private tender, as well as, for the secured creditor to keep the asset in satisfaction of the debt?

Figure - Credit Information in Ukraine and comparator economies

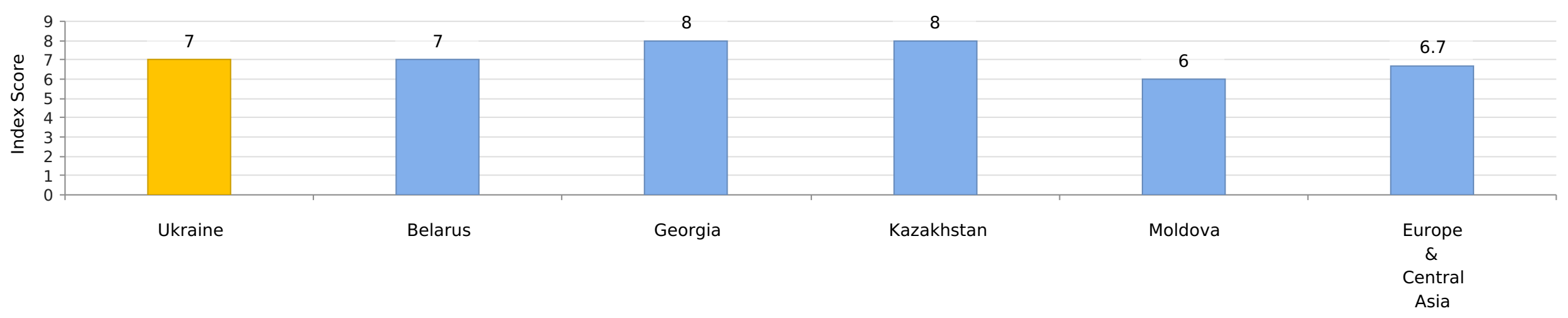




\section{Details - Credit Information in Ukraine}

Depth of credit information index (0-8)

Credit bureau

Yes

Yes

No

Are data from retailers or utility companies - in addition to data from banks and

financial institutions - distributed?

Are data on both firms and individuals distributed?
Credit registry

\section{Score}

No

No
Are at least 2 years of historical data distributed? (Credit bureaus and registries that distribute more than 10 years of negative data or erase data on defaults as soon as they are repaid obtain a score of 0 for this component.)

Yes Yes

Are data on loan amounts below $1 \%$ of income per capita distributed?

By law, do borrowers have the right to access their data in the credit bureau or credit registry?

Yes
Yes

Can banks and financial institutions access borrowers' credit information online (for example, through an online platform, a system-to-system connection or both)?

Are bureau or registry credit scores offered as a value-added service to help banks and financial institutions assess the creditworthiness of borrowers?

Total Score ("yes" to either public bureau or private registry)

Yes
No

No

1

1

0

1 1

No 1
1

1

Note: An economy receives a score of 1 if there is a "yes" to either bureau or registry. If the credit bureau or registry is not operational or covers less than $5 \%$ of the adult population, the total score on the depth of credit information index is 0 .

\section{Coverage}

Number of individuals

Number of firms

Total
Credit bureau

$16,900,000$

213,000

$17,113,000$

\section{Credit registry}

576,025

147,517

723,542 


\section{Protecting Minority Investors}

This topic measures the strength of minority shareholder protections against misuse of corporate assets by directors for their personal gain as well as shareholder rights, governance safeguards and corporate transparency requirements that reduce the risk of abuse. The most recent round of data collection for the project was completed in May 2019. See the methodology for more information.

\section{What the indicators measure}

- Extent of disclosure index (0-10): Disclosure, review, and approval requirements for related-party transactions

- Extent of director liability index (0-10): Ability of minority shareholders to sue and hold interested directors liable for prejudicial related-party transactions; Available legal remedies (damages, disgorgement of profits, disqualification from managerial position(s) for one year or more, rescission of the transaction)

- Ease of shareholder suits index (0-10): Access to interna corporate documents; Evidence obtainable during trial and allocation of legal expenses

- Extent of conflict of interest regulation index (0-30): Sum of the extent of disclosure, extent of director liability and ease of shareholder suits indices

- Extent of shareholder rights index (0-6): Shareholders' rights and role in major corporate decisions

- Extent of ownership and control index (0-7): Governance safeguards protecting shareholders from undue board control and entrenchment

- Extent of corporate transparency index (0-7): Corporate transparency on ownership stakes, compensation, audits and financial prospects

- Extent of shareholder governance index (0-20): Sum of the extent of shareholders rights, extent of ownership and control and extent of corporate transparency indices

- Strength of minority investor protection index (0-50): Sum of the extent of conflict of interest regulation and extent of shareholder governance indices

\section{Case study assumptions}

To make the data comparable across economies, a case study uses several assumptions about the business and the transaction.

\section{The business (Buyer):}

- Is a publicly traded corporation listed on the economy's most important stock exchange.

- Has a board of directors and a chief executive officer (CEO) who may legally act on behalf of Buyer where permitted, even if this is not specifically required by law.

- Has a supervisory board in economies with a two-tier board system on which Mr. James appointed $60 \%$ of the shareholder-elected members.

- Has not adopted bylaws or articles of association that go beyond the minimum requirements. Does not follow codes, principles, recommendations or guidelines that are not mandatory. - Is a manufacturing company with its own distribution network.

The transaction involves the following details:

- Mr. James owns $60 \%$ of Buyer, sits on Buyer's board of directors and elected two directors to Buyer's five-member board.

- Mr. James also owns $90 \%$ of Seller, a company that operates a chain of retail hardware stores. Seller recently closed a large number of its stores.

- Mr. James proposes that Buyer purchase Seller's unused fleet of trucks to expand Buyer's distribution of its food products, a proposal to which Buyer agrees. The price is equal to $10 \%$ of Buyer's assets and is higher than the market value.

- The proposed transaction is part of the company's principal activity and is not outside the authority of the company.

- Buyer enters into the transaction. All required approvals are obtained, and all required disclosures made-that is, the transaction was not entered into fraudulently.

- The transaction causes damages to Buyer. Shareholders sue Mr. James and the executives and directors that approved the transaction. 


\section{Protecting Minority Investors - Ukraine}

\section{dataPointName}

Stock exchange

Ukrainian Exchange

Stock exchange URL

http://www.ux.ua/en/

Listed firms with equity securities

City Covered

Kyiv

\begin{tabular}{|c|c|c|c|c|}
\hline Indicator & Ukraine & $\begin{array}{l}\text { Europe \& Central } \\
\text { Asia }\end{array}$ & $\begin{array}{l}\text { OECD high } \\
\text { income }\end{array}$ & $\begin{array}{l}\text { Best Regulatory } \\
\text { Performance }\end{array}$ \\
\hline Extent of disclosure index $(0-10)$ & 9.0 & 7.5 & 6.5 & 10 (13 Economies) \\
\hline Extent of director liability index $(0-10)$ & 2.0 & 5.0 & 5.3 & 10 (3 Economies) \\
\hline Ease of shareholder suits index $(0-10)$ & 6.0 & 6.8 & 7.3 & 10 (Djibouti) \\
\hline Extent of shareholder rights index $(0-6)$ & 4.0 & 3.4 & 4.7 & 6 (19 Economies) \\
\hline Extent of ownership and control index (0-7) & 6.0 & 3.7 & 4.5 & 7 (9 Economies) \\
\hline Extent of corporate transparency index $(0-7)$ & 7.0 & 4.1 & 5.7 & 7 (13 Economies) \\
\hline
\end{tabular}

Figure - Protecting Minority in Ukraine - Score

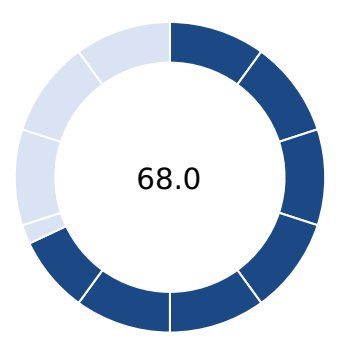

Score - Protecting Minority Investors

Figure - Protecting Minority Investors in Ukraine and comparator economies - Ranking and Score

DB 2020 Protecting Minority Investors Score

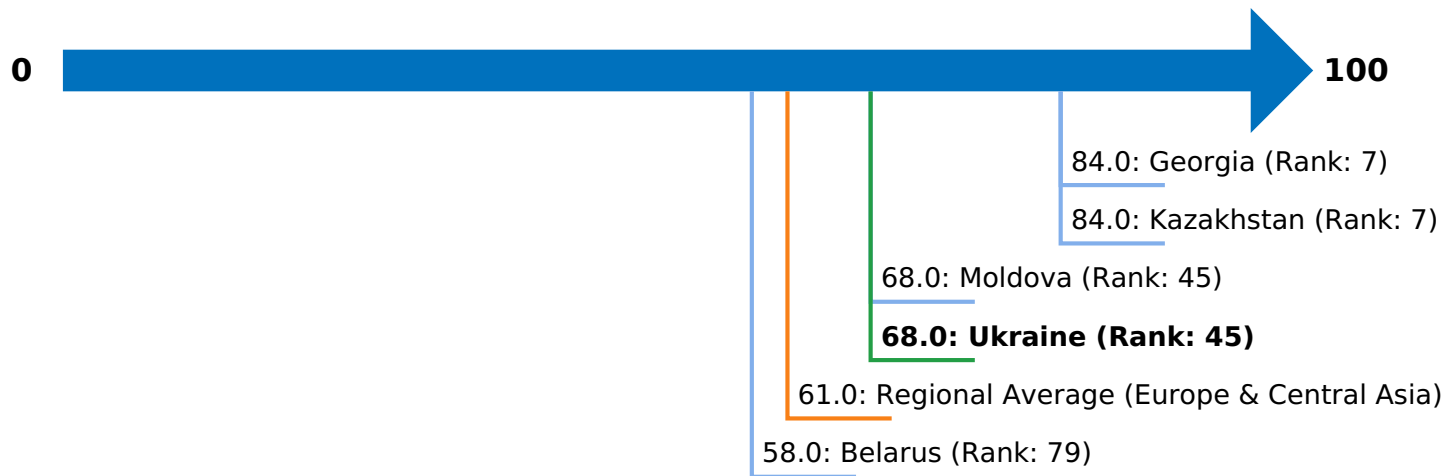

Note: The ranking of economies on the strength of minority investor protections is determined by sorting their scores for protecting minority investors. These scores are the simple average of the scores for the extent of conflict of interest regulation index and the extent of shareholder governance index. 


\section{Figure - Protecting Minority Investors in Ukraine and comparator economies - Measure of Quality}

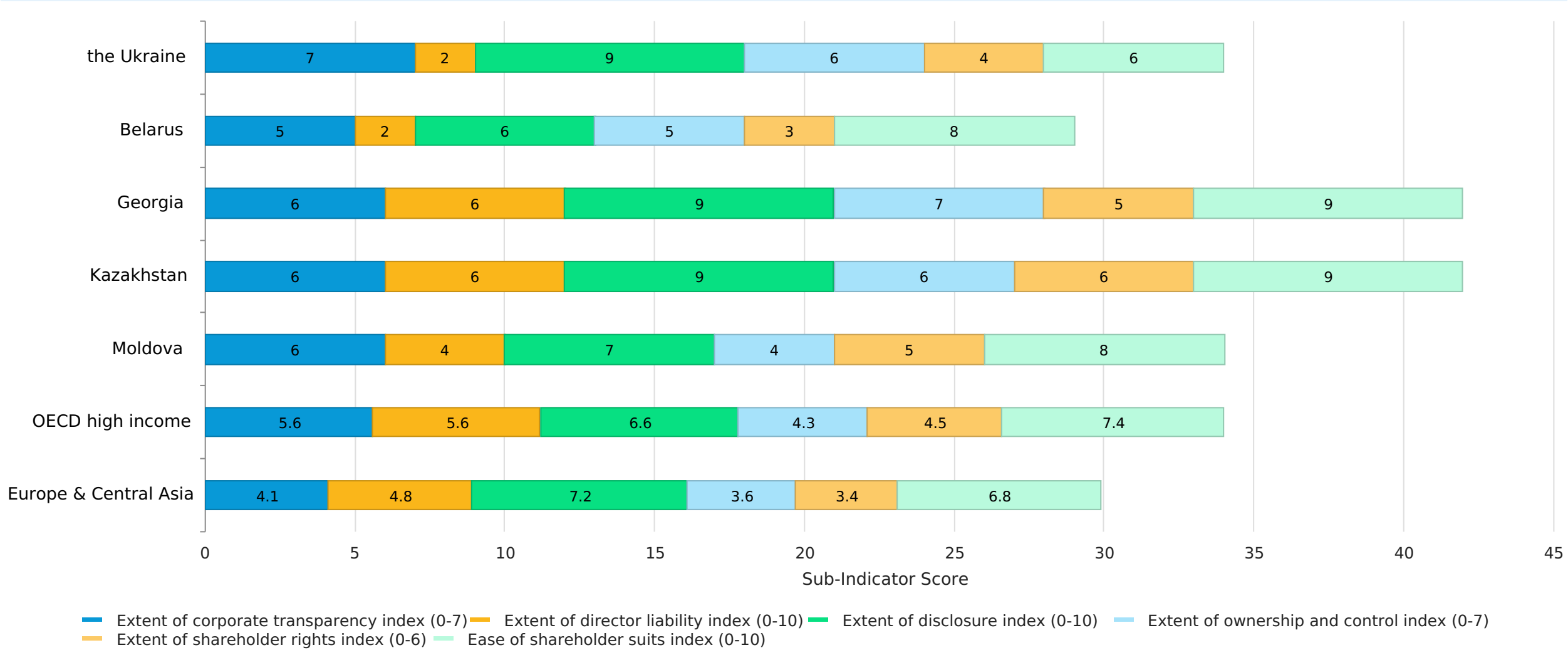




\section{Details - Protecting Minority Investors in Ukraine - Measure of Quality}

Extent of conflict of interest regulation index (0-30)

Extent of disclosure index (0-10)

Whose decision is sufficient to approve the Buyer-Seller transaction? (0-3)

Board of directors

Must an external body review the terms of the transaction before it takes place? (0-1)

Yes

Must Mr. James disclose his conflict of interest to the board of directors? $(0-2)$

Full disclosure of all $\quad 2.0$ material facts

Must Buyer disclose the transaction in periodic filings (e.g. annual reports)? (0-2)

Disclosure on the

transaction and on

the conflict of interest

Must Buyer immediately disclose the transaction to the public? (0-2)

Disclosure on the transaction and on the conflict of interest

\section{Extent of director liability index (0-10)}

Can shareholders representing $10 \%$ of Buyer's share capital sue for the damage the transaction caused to Buyer? (0-1)

\begin{tabular}{l|l} 
& $\mathbf{2 . 0}$ \\
\hline Yes & 1.0 \\
\hline
\end{tabular}

Can shareholders hold Mr. James liable for the damage the transaction caused to Buyer? (0-2)

Not liable

Can shareholders hold the other directors liable for the damage the transaction caused to Buyer? (0-2)

Liable if negligent

Must Mr. James pay damages for the harm caused to Buyer upon a successful claim by shareholders? $(0-1)$

No

0.0

Must Mr. James repay profits made from the transaction upon a successful claim by shareholders? (0-1)

No

Is Mr. James disqualified upon a successful claim by shareholders? (0-1)

No

0.0

Can a court void the transaction upon a successful claim by shareholders? (0-2)

Only in case of fraud $\quad 0.0$ or bad faith

\section{Ease of shareholder suits index (0-10)}

Before suing, can shareholders representing $10 \%$ of Buyer's share capital inspect the transaction documents? $(0-1)$

Can the plaintiff obtain any documents from the defendant and witnesses at trial? (0-3)

Can the plaintiff request categories of documents from the defendant without identifying specific ones? (0-1)

Can the plaintiff directly question the defendant and witnesses at trial? (0-2)

Yes

2.0

Is the level of proof required for civil suits lower than that of criminal cases? (0-1)

No

Can shareholder plaintiffs recover their legal expenses from the company? (0-2)

Yes if successful

1.0

Extent of shareholder governance index (0-20)

Extent of shareholder rights index (0-6)

Does the sale of $51 \%$ of Buyer's assets require shareholder approval?

Do shareholders elect and dismiss the external auditor?

Are changes to the rights of a class of shares only possible if the holders of the affected shares approve?
Yes

Yes

Yes

No

No

1.0

1.0

1.0

0.0

Yes

1.0 
Can shareholders remove members of the board of directors without cause before the end of their term?

Must the board of directors include a separate audit committee exclusively comprising board members?

Must a potential acquirer make a tender offer to all shareholders upon acquiring $50 \%$ of Buyer?

Must Buyer pay declared dividends within a maximum period set by law?

Is a subsidiary prohibited from acquiring shares issued by its parent company?

\section{Extent of corporate transparency index (0-7)}

Must Buyer disclose direct and indirect beneficial ownership stakes representing 5\%?

Must Buyer disclose information about board members' primary employment and directorships in other companies?

Must Buyer disclose the compensation of individual managers? 


\section{Paying Taxes}

This topic records the taxes and mandatory contributions that a medium-size company must pay or withhold in a given year, as well as the administrative burden of paying taxes and contributions and complying with postfiling procedures (VAT refund and tax audit). The most recent round of data collection for the project was completed in May 2019 covering for the Paying Taxes indicator calendar year 2018 (January 1, 2018 - December 31, 2018). See the methodology for more information.

What the indicators measure

Tax payments for a manufacturing company in 2018 (number per year adjusted for electronic and joint filing and payment)

- Total number of taxes and contributions paid or withheld, including consumption taxes (value added tax, sales tax or goods and service tax)

- Method and frequency of filing and payment

Time required to comply with $\mathbf{3}$ major taxes (hours per year)

- Collecting information, computing tax payable

- Preparing separate tax accounting books, if required

- Completing tax return, filing with agencies

- Arranging payment or withholding

\section{Total tax and contribution rate (\% of commercial profits)}

- Profit or corporate income tax

- Social contributions, labor taxes paid by employer

- Property and property transfer taxes

- Dividend, capital gains, financial transactions taxes

- Waste collection, vehicle, road and other taxes

\section{Postfiling Index}

- Time to comply with VAT refund (hours)

- Time to obtain VAT refund (weeks)

- Time to comply with a corporate income tax correction (hours)

- Time to complete a corporate income tax correction (weeks)
Case study assumptions

Using a case scenario, Doing Business records taxes and mandatory contributions a medium size company must pay in a year, and measures the administrative burden of paying taxes, contributions and dealing with postfiling processes. Information is also compiled on frequency of filing and payments, time taken to comply with tax laws, time taken to comply with the requirements of postfiling processes and time waiting.

To make data comparable across economies, several assumptions are used

- TaxpayerCo is a medium-size business that started operations on January 1,2017 . It produces ceramic flowerpots and sells them at retail. All taxes and contributions recorded are paid in the second year of operation (calendar year 2018). Taxes and mandatory contributions are measured at all levels of government.

\section{The VAT refund process:}

- In June 2018, TaxpayerCo. makes a large capital purchase: the value of the machine is 65 times income per capita of the economy. Sales are equally spread per month (1,050 times income per capita divided by 12) and cost of goods sold are equally expensed per month (875 times income per capita divided by 12). The machinery seller is registered for VAT and excess input VAT incurred in June will be fully recovered after four consecutive months if the VAT rate is the same for inputs, sales and the machine and the tax reporting period is every month. Input VAT will exceed Output VAT in June 2018

The corporate income tax audit process:

- An error in calculation of income tax liability (for example, use of incorrect tax depreciation rates or incorrectly treating an expense as tax deductible) leads to an incorrect income tax return and a corporate income tax underpayment. TaxpayerCo. discovered the error and voluntarily notified the tax authority. The value of the underpaid income tax liability is $5 \%$ of the corporate income tax liability due. TaxpayerCo. submits corrected information after the deadline for submitting the annual tax return, but within the tax assessment period. 


\section{Paying Taxes - Ukraine}

\begin{tabular}{|c|c|c|c|c|}
\hline Indicator & Ukraine & $\begin{array}{l}\text { Europe \& Central } \\
\text { Asia }\end{array}$ & $\begin{array}{l}\text { OECD high } \\
\text { income }\end{array}$ & $\begin{array}{l}\text { Best Regulatory } \\
\text { Performance }\end{array}$ \\
\hline Payments (number per year) & 5 & 14.4 & 10.3 & 3 (2 Economies) \\
\hline Time (hours per year) & 328 & 213.1 & 158.8 & 49 (3 Economies) \\
\hline Total tax and contribution rate ( $\%$ of profit) & 45.2 & 31.7 & 39.9 & 26.1 (33 Economies) \\
\hline Postfiling index (0-100) & 86.0 & 68.2 & 86.7 & None in 2018/19 \\
\hline
\end{tabular}

Figure - Paying Taxes in Ukraine - Score

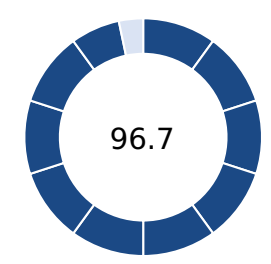

Payments

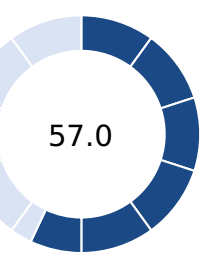

Time

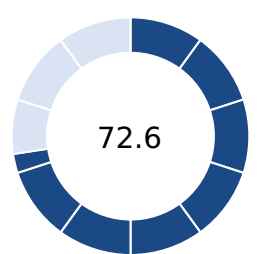

Total tax and contribution rate

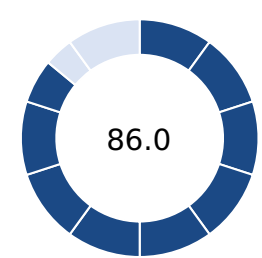

Postfiling index

Figure - Paying Taxes in Ukraine and comparator economies - Ranking and Score

DB 2020 Paying Taxes Score

o

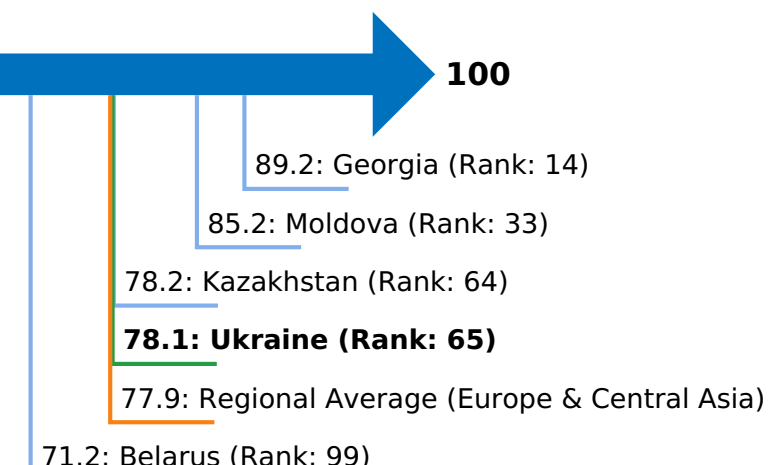

Note: The ranking of economies on the ease of paying taxes is determined by sorting their scores for paying taxes. These scores are the simple average of the scores for each of the component indicators, with a threshold and a nonlinear transformation applied to one of the component indicators, the total tax and contribution rate. The threshold is defined as the total tax and contribution rate at the 15th percentile of the overall distribution for all years included in the analysis up to and including Doing Business 2015 , which is $26.1 \%$. All economies with a total tax and contribution rate below this threshold receive the same score as the economy at the threshold. 
Figure - Paying Taxes in Ukraine and comparator economies - Measure of Quality

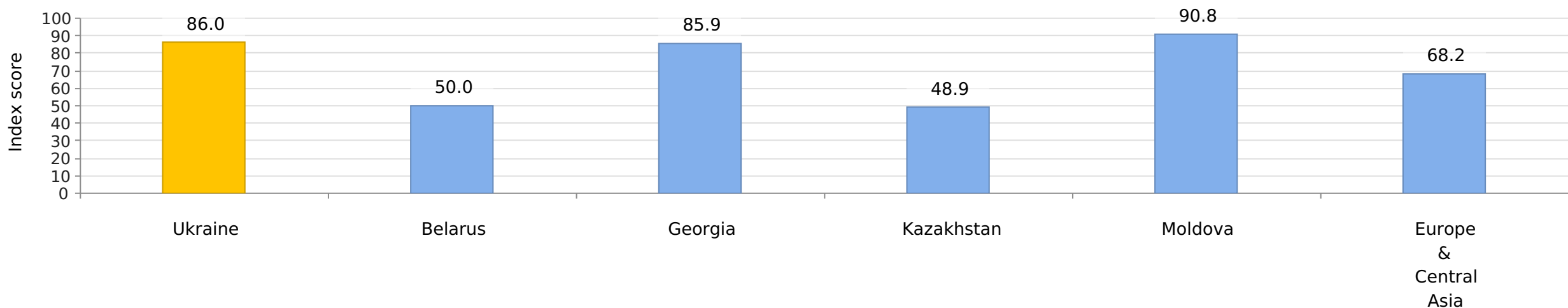


Details - Paying Taxes in Ukraine

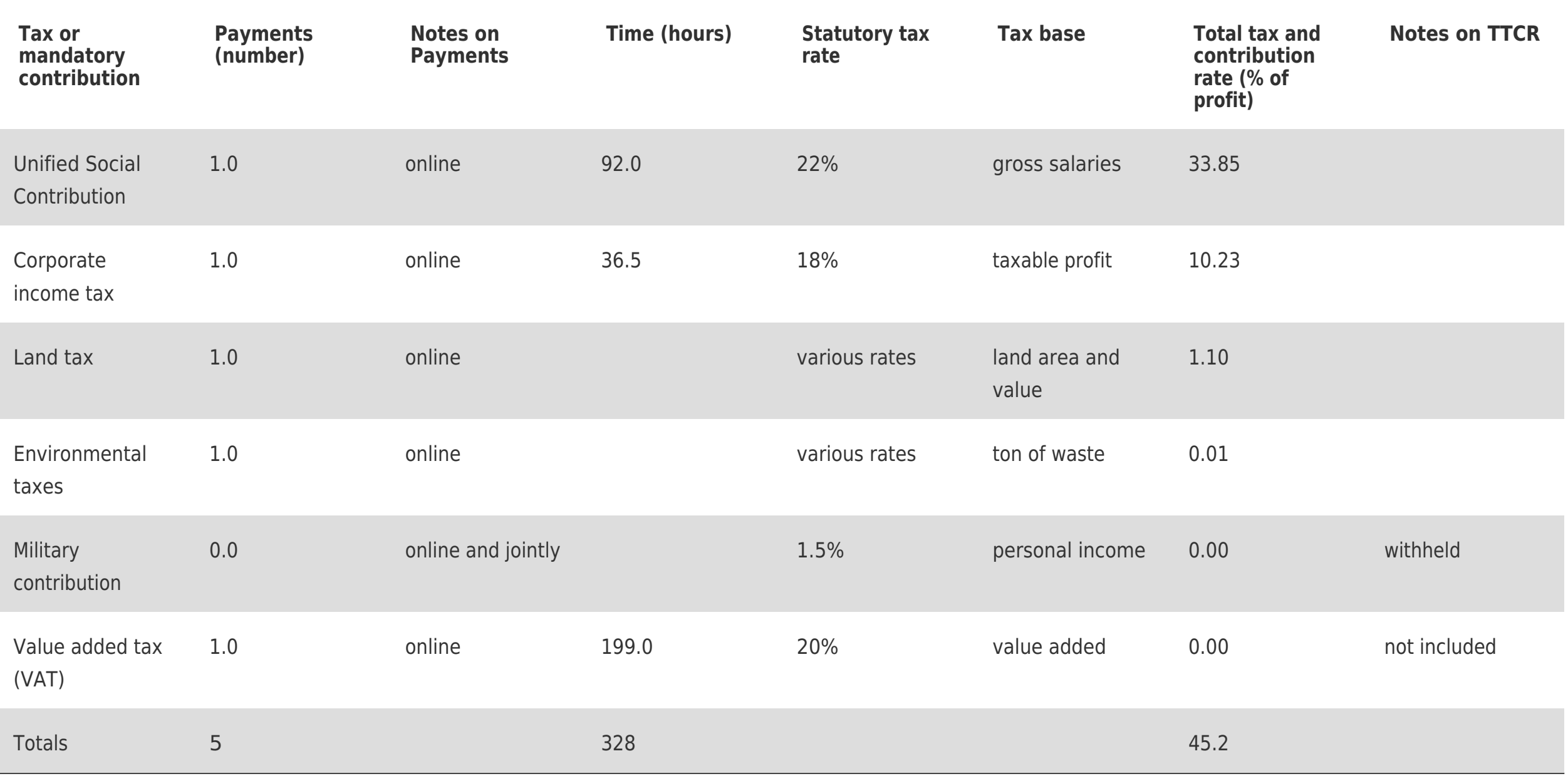


Details - Paying Taxes in Ukraine - Tax by Type

Taxes by type

Answer

Profit tax (\% of profit)

10.2

Labor tax and contributions ( $\%$ of profit)

33.8

Other taxes (\% of profit)

1.1 


\section{Details - Paying Taxes in Ukraine - Measure of Quality}

Answer

Score

Postfiling index (0-100)

\section{VAT refunds}

Does VAT exist?

Does a VAT refund process exist per the case study?

Restrictions on VAT refund process

Percentage of cases exposed to a VAT audit (\%)

Is there a mandatory carry forward period?

Time to comply with VAT refund (hours)

Time to obtain VAT refund (weeks)

\section{Corporate income tax audits}

Does corporate income tax exist?

Percentage of cases exposed to a corporate income tax audit (\%)

Time to comply with a corporate income tax correction (hours)

Time to complete a corporate income tax correction (weeks)
Yes

Yes

none
Yes

$75 \%-100 \%$

No

16.0

68.0

14.0

78.6

\author{
$0 \%-24 \%$
}

3.0

97.2

No tax audit per case 100

study scenario

Notes: Names of taxes have been standardized. For instance income tax, profit tax, tax on company's income are all named corporate income tax in this table. The hours for VAT include all the VAT and sales taxes applicable.

The hours for Social Security include all the hours for labor taxes and mandatory contributions in general.

The postfiling index is the average of the scores on time to comply with VAT refund, time to obtain a VAT refund, time to comply with a corporate income tax correction and time to complete a corporate income tax correction.

$\mathrm{N} / \mathrm{A}=$ Not applicable 


\section{Trading across Borders}

Doing Business records the time and cost associated with the logistical process of exporting and importing goods. Doing Business measures the time and cost (excluding tariffs) associated with three sets of procedures-documentary compliance, border compliance and domestic transport-within the overall process of exporting or importing a shipment of goods. The most recent round of data collection for the project was completed in May 2019. See the methodology for more information.

What the indicators measure

\section{Documentary compliance}

- Obtaining, preparing and submitting documents during transport, clearance, inspections and port or border handling in origin economy

- Obtaining, preparing and submitting documents required by destination economy and any transit economies

- Covers all documents required by law and in practice, including electronic submissions of information

\section{Border compliance}

- Customs clearance and inspections

- Inspections by other agencies (if applied to more than $20 \%$ of shipments)

- Handling and inspections that take place at the economy's port or border

\section{Domestic transport}

- Loading or unloading of the shipment at the warehouse or port/border

- Transport between warehouse and port/border

- Traffic delays and road police checks while shipment is en route
Case study assumptions

To make the data comparable across economies, a few assumptions are made about the traded goods and the transactions:

Time: Time is measured in hours, and 1 day is 24 hours (for example, 22 days are recorded as $22 \times 24=528$ hours). If customs clearance takes 7.5 hours, the data are recorded as is. Alternatively, suppose documents are submitted to a customs agency at 8:00a.m., are processed overnight and can be picked up at 8:00a.m. the next day. The time for customs clearance would be recorded as 24 hours because the actual procedure took 24 hours.

Cost: Insurance cost and informal payments for which no receipt is issued are excluded from the costs recorded. Costs are reported in U.S. dollars. Contributors are asked to convert local currency into U.S. dollars based on the exchange rate prevailing on the day they answer the questionnaire. Contributors are private sector experts in international trade logistics and are informed about exchange rates.

\section{Assumptions of the case study:}

- For all 190 economies covered by Doing Business, it is assumed a shipment is in a warehouse in the largest business city of the exporting economy and travels to a warehouse in the largest business city of the importing economy.

- It is assumed each economy imports 15 metric tons of containerized auto parts (HS 8708) from its natural import partner-the economy from which it imports the largest value (price times quantity) of auto parts. It is assumed each economy exports the product of its comparative advantage (defined by the largest export value) to its natural export partner-the economy that is the largest purchaser of this product. Shipment value is assumed to be $\$ 50,000$.

- The mode of transport is the one most widely used for the chosen export or import product and the trading partner, as is the seaport or land border crossing.

- All electronic information submissions requested by any government agency in connection with the shipment are considered to be documents obtained, prepared and submitted during the export or import process.

- A port or border is a place (seaport or land border crossing) where merchandise can enter or leave an economy.

- Relevant government agencies include customs, port authorities, road police, border guards, standardization agencies, ministries or departments of agriculture or industry, national security agencies and any other government authorities. 


\section{Trading across Borders - Ukraine}

\begin{tabular}{|c|c|c|c|c|}
\hline Indicator & Ukraine & $\begin{array}{l}\text { Europe \& Central } \\
\text { Asia }\end{array}$ & $\begin{array}{l}\text { OECD high } \\
\text { income }\end{array}$ & $\begin{array}{l}\text { Best Regulatory } \\
\text { Performance }\end{array}$ \\
\hline Time to export: Border compliance (hours) & 6 & 16.1 & 12.7 & 1 (19 Economies) \\
\hline Cost to export: Border compliance (USD) & 75 & 150.0 & 136.8 & 0 (19 Economies) \\
\hline Time to export: Documentary compliance (hours) & 66 & 25.1 & 2.3 & 1 (26 Economies) \\
\hline Cost to export: Documentary compliance (USD) & 192 & 87.6 & 33.4 & 0 (20 Economies) \\
\hline Time to import: Border compliance (hours) & 32 & 20.4 & 8.5 & 1 (25 Economies) \\
\hline Cost to import: Border compliance (USD) & 100 & 158.8 & 98.1 & 0 (28 Economies) \\
\hline Time to import: Documentary compliance (hours) & 48 & 23.4 & 3.4 & 1 (30 Economies) \\
\hline Cost to import: Documentary compliance (USD) & 162 & 85.9 & 23.5 & 0 (30 Economies) \\
\hline
\end{tabular}

Figure - Trading across Borders in Ukraine - Score
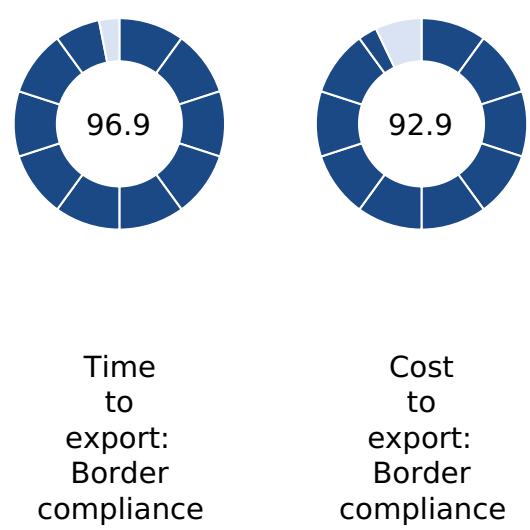
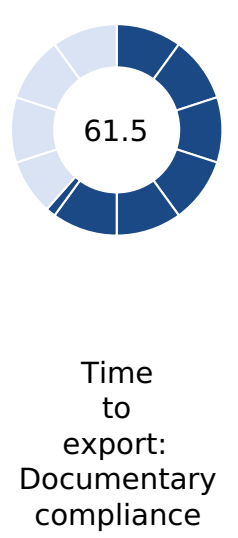

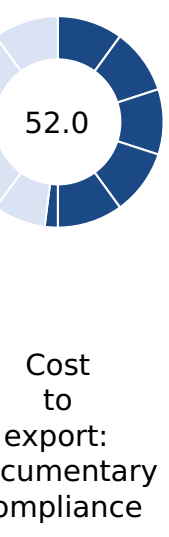

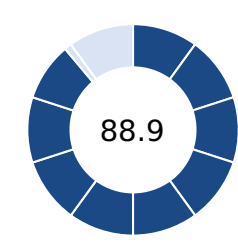
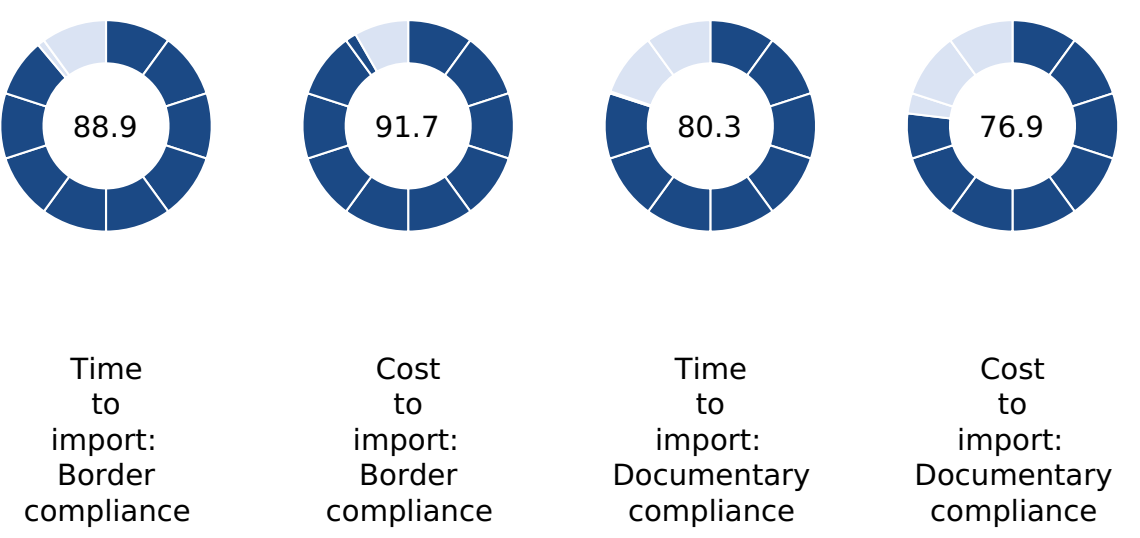

Time
to
import:
Documentary
compliance

Figure - Trading across Borders in Ukraine and comparator economies - Ranking and Score

DB 2020 Trading Across Borders Score

$\mathbf{0}$

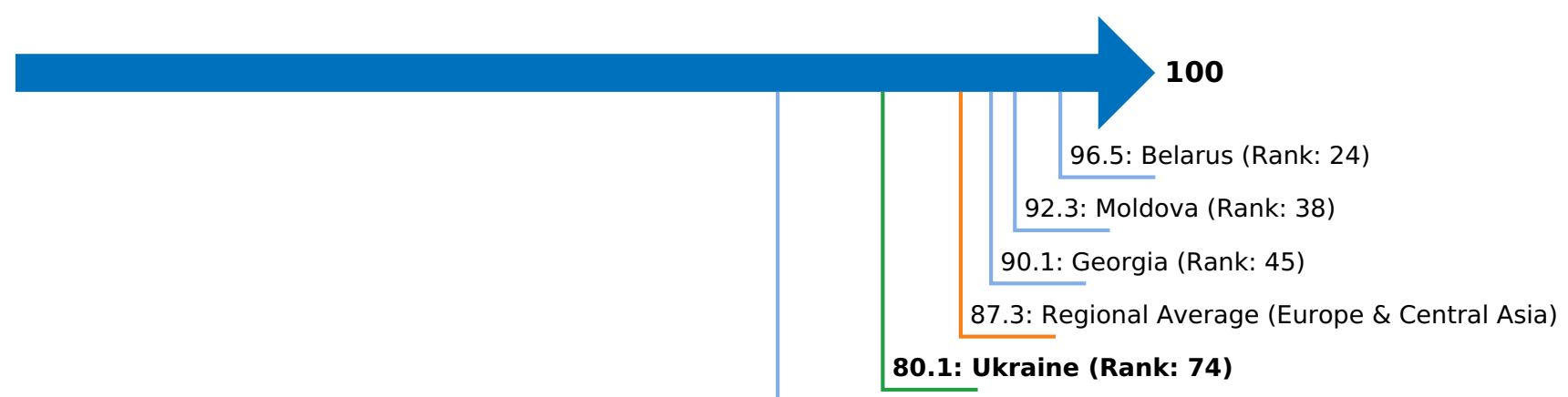

70.4: Kazakhstan (Rank: 105)

Note: The ranking of economies on the ease of trading across borders is determined by sorting their scores for trading across borders. These scores are the simple average of the scores for the time and cost for documentary compliance and border compliance to export and import. 
Figure - Trading across Borders in Ukraine - Time and Cost

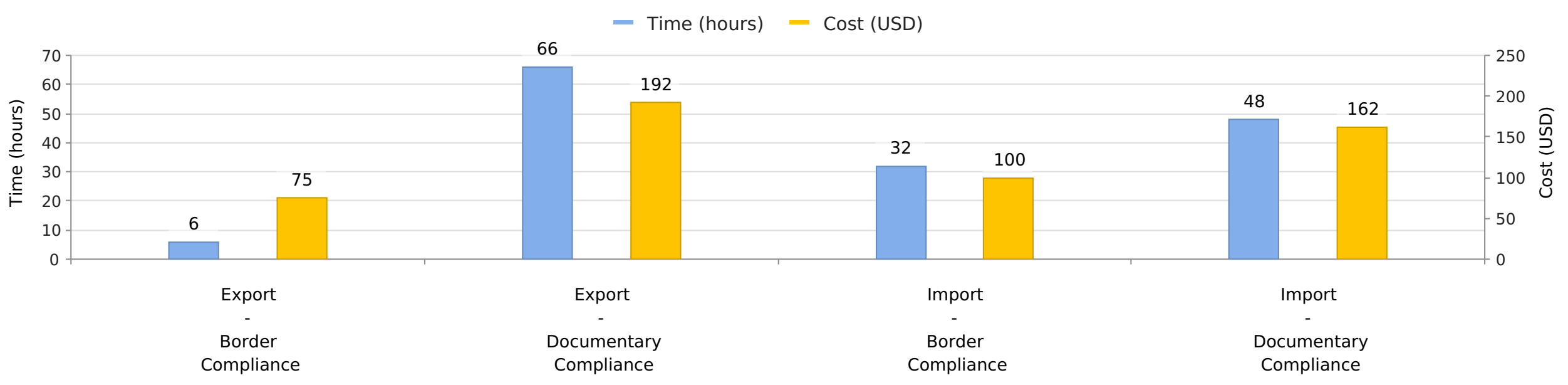


Details - Trading across Borders in Ukraine

\section{Characteristics}

Product

Trade partner

Border

\section{Export}

HS 72 : Iron and steel
Import

HS 8708: Parts and accessories of motor vehicles

Russian Federation

Kharkiv Oblast border crossing (GoptovkaNehoteevka)

335

5

300

Domestic transport cost (USD)

300

Associated Costs (USD)

Details - Trading across Borders in Ukraine - Components of Border Compliance

Time to Complete (hours)

Export: Clearance and inspections required by

customs authorities

Export: Clearance and inspections required by

0.0

agencies other than customs

Export: Port or border handling

Import: Clearance and inspections required by customs authorities

Import: Clearance and inspections required by

agencies other than customs 
Details - Trading across Borders in Ukraine - Trade Documents

Export

Act of loading

Certificate of origin

Certificate of quality

CMR waybill

Commercial invoice

Contract

Customs export declaration
Import

Certificate of conformity

CMR Waybill

Commercial invoice

Contract

Customs import declaration

Packing list

Preliminary import declaration

Specification of the product 


\section{IIII Enforcing Contracts}

The enforcing contracts indicator measures the time and cost for resolving a commercial dispute through a local first-instance court, and the quality of judicial processes index, evaluating whether each economy has adopted a series of good practices that promote quality and efficiency in the court system. The most recent round of data collection was completed in May 2019. See the methodology for more information.

\section{What the indicators measure}

\section{Time required to enforce a contract through the courts} (calendar days)

- Time to file and serve the case

- Time for trial and to obtain the judgment

- Time to enforce the judgment

Cost required to enforce a contract through the courts (\% of claim value)

- Average attorney fees

- Court costs

- Enforcement costs

\section{Quality of judicial processes index (0-18)}

- Court structure and proceedings (-1-5

- Case management (0-6)

- Court automation (0-4)

- Alternative dispute resolution (0-3)

\section{Case study assumptions}

The dispute in the case study involves the breach of a sales contract between two domestic businesses. The case study assumes that the court hears an expert on the quality of the goods in dispute. This distinguishes the case from simple debt enforcement.

To make the data on the time and comparable across economies, several assumptions about the case are used:

- The dispute concerns a lawful transaction between two businesses (Seller and Buyer), both located in the economy's largest business city. For 11 economies the data are also collected for the second largest business city.

- The Buyer orders custom-made furniture, then fails to pay alleging that the goods are not of adequate quality.

- The value of the dispute is $200 \%$ of the income per capita or the equivalent in local currency of USD 5,000, whichever is greater.

- The Seller sues the Buyer before the court with jurisdiction over commercial cases worth $200 \%$ of income per capita or $\$ 5,000$ whichever is greater.

- The Seller requests the pretrial attachment of the defendant's movable assets to secure the claim.

- The claim is disputed on the merits because of Buyer's allegation that the quality of the goods was not adequate.

- The judge decides in favor of the seller; there is no appeal.

- The Seller enforces the judgment through a public sale of the Buyer's movable assets. 


\section{Enforcing Contracts - Ukraine}

\section{Standardized Case}

$\begin{array}{lll}\text { Claim value } & \text { UAH } 150,953\end{array}$

Court name Kiev Commercial Court

City Covered Kyiv

\begin{tabular}{|c|c|c|c|c|}
\hline Indicator & Ukraine & $\begin{array}{l}\text { Europe \& Central } \\
\text { Asia }\end{array}$ & $\begin{array}{l}\text { OECD high } \\
\text { income }\end{array}$ & $\begin{array}{l}\text { Best Regulatory } \\
\text { Performance }\end{array}$ \\
\hline Cost ( $\%$ of claim value) & 46.3 & 26.6 & 21.5 & 0.1 (Bhutan) \\
\hline
\end{tabular}

Figure - Enforcing Contracts in Ukraine - Score

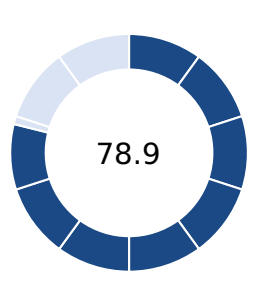

Time

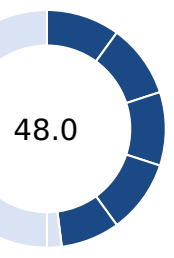

Cost

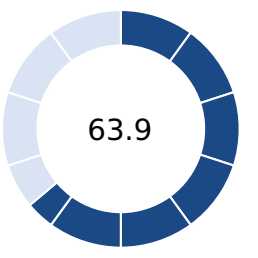

Quality of judicial processes index

Figure - Enforcing Contracts in Ukraine and comparator economies - Ranking and Score

DB 2020 Enforcing Contracts Score

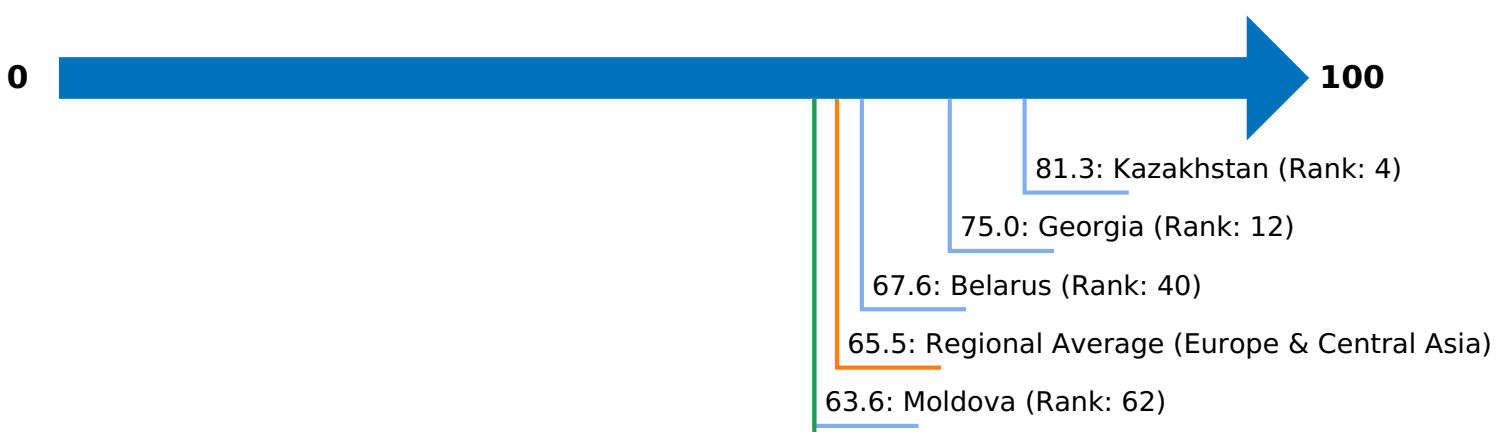

63.6: Ukraine (Rank: 63)

Note: The ranking of economies on the ease of enforcing contracts is determined by sorting their scores for enforcing contracts. These scores are the simple average of the scores for each of the component indicators. 
Figure - Enforcing Contracts in Ukraine - Time and Cost

- Time (days) - Cost ( $\%$ of claim value)

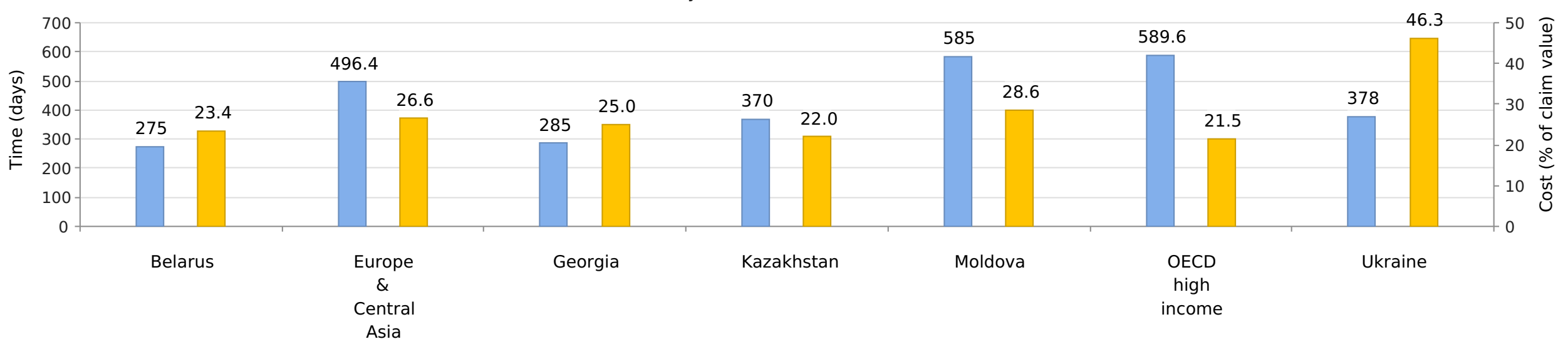




\section{Figure - Enforcing Contracts in Ukraine and comparator economies - Measure of Quality}

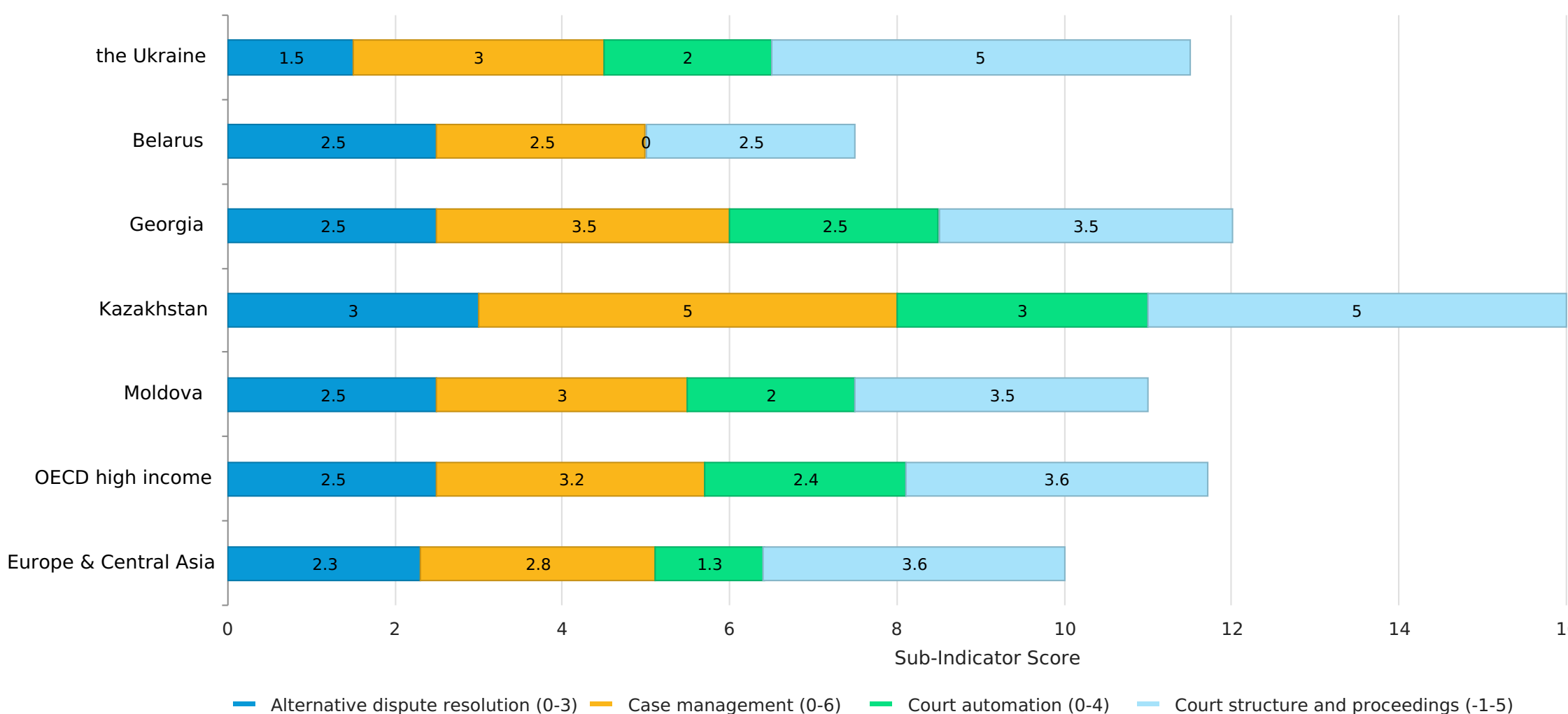

\section{Details - Enforcing Contracts in Ukraine}

\section{Indicator}

Time (days)

Filing and service

48

Trial and judgment

Enforcement of judgment

180

Cost (\% of claim value)

46.3

Attorney fees

25

Court fees

Enforcement fees

Quality of judicial processes index (0-18)

Court structure and proceedings (-1-5) 


\section{Details - Enforcing Contracts in Ukraine - Measure of Quality}

Answer

Score

Quality of judicial processes index (0-18)

Court structure and proceedings (-1-5)

5.0

1. Is there a court or division of a court dedicated solely to hearing commercial cases?

1.5

2. Small claims court

1.5

2.a. Is there a small claims court or a fast-track procedure for small claims?

Yes

2.b. If yes, is self-representation allowed?

Yes

3. Is pretrial attachment available?

Yes

1.0

4. Are new cases assigned randomly to judges?

Yes, automatic

1.0

5. Does a woman's testimony carry the same evidentiary weight in court as a man's?

Yes

0.0

\section{Case management (0-6)}

3.0

1. Time standards

1.0

1.a. Are there laws setting overall time standards for key court events in a civil case?

Yes

1.b. If yes, are the time standards set for at least three court events?

Yes

1.c. Are these time standards respected in more than $50 \%$ of cases?

2. Adjournments

Yes

2.a. Does the law regulate the maximum number of adjournments that can be granted?

No

2.b. Are adjournments limited to unforeseen and exceptional circumstances?

No

2.c. If rules on adjournments exist, are they respected in more than $50 \%$ of cases?

3. Can two of the following four reports be generated about the competent court: (i) time to disposition report; (ii) Yes clearance rate report; (iii) age of pending cases report; and (iv) single case progress report?

4. Is a pretrial conference among the case management techniques used before the competent court?

Yes

1.0

5. Are there any electronic case management tools in place within the competent court for use by judges?

No

6. Are there any electronic case management tools in place within the competent court for use by lawyers?

No

0.0

Court automation (0-4)

2.0

1. Can the initial complaint be filed electronically through a dedicated platform within the competent court?

No

0.0

2. Is it possible to carry out service of process electronically for claims filed before the competent court?

No

0.0

3. Can court fees be paid electronically within the competent court?

Yes

1.0

4. Publication of judgments

4. a Are judgments rendered in commercial cases at all levels made available to the general public through publication in official gazettes, in newspapers or on the internet or court website?

4.b. Are judgments rendered in commercial cases at the appellate and supreme court level made available to the general public through publication in official gazettes, in newspapers or on the internet or court website?

Alternative dispute resolution (0-3)

1.a. Is domestic commercial arbitration governed by a consolidated law or consolidated chapter or section of the applicable code of civil procedure encompassing substantially all its aspects?

1.b. Are there any commercial disputes-aside from those that deal with public order or public policy- Yes that cannot be submitted to arbitration? 
2.b. Are mediation, conciliation or both governed by a consolidated law or consolidated chapter or

section of the applicable code of civil procedure encompassing substantially all their aspects (for example, definition, aim and scope of application, designation of mediator/conciliator, initiation of the process, principles governing the process, enforcement)?

2.c. Are there financial incentives for parties to attempt mediation or conciliation (i.e., if mediation or conciliation is successful, a refund of court filing fees, income tax credits or the like)? 


\section{Resolving Insolvency}

Doing Business studies the time, cost and outcome of insolvency proceedings involving domestic legal entities. These variables are used to calculate the recovery rate, which is recorded as cents on the dollar recovered by secured creditors through reorganization, liquidation or debt enforcement (foreclosure or receivership) proceedings. To determine the present value of the amount recovered by creditors, Doing Business uses the lending rates from the International Monetary Fund, supplemented with data from central banks and the Economist Intelligence Unit. The most recent round of data collection was completed in May 2019. See the methodology for more information.

What the indicators measure

\section{Time required to recover debt (years)}

- Measured in calendar years

- Appeals and requests for extension are included

\section{Cost required to recover debt (\% of debtor's estate)}

- Measured as percentage of estate value

- Court fees

- Fees of insolvency administrators

- Lawyers' fees

- Assessors' and auctioneers' fees

- Other related fees

\section{Outcome}

- Whether business continues operating as a going concern or business assets are sold piecemeal

\section{Recovery rate for creditors}

- Measures the cents on the dollar recovered by secured creditors

- Outcome for the business (survival or not) determines the maximum value that can be recovered

- Official costs of the insolvency proceedings are deducted

- Depreciation of furniture is taken into account

- Present value of debt recovered

\section{Strength of insolvency framework index (0-16)}

- Sum of the scores of four component indices:

- Commencement of proceedings index (0-3)

- Management of debtor's assets index (0-6)

- Reorganization proceedings index (0-3)

- Creditor participation index (0-4)

\section{Case study assumptions}

To make the data on the time, cost and outcome comparable across economies, severa assumptions about the business and the case are used:

- A hotel located in the largest city (or cities) has 201 employees and 50 suppliers. The hotel experiences financial difficulties.

- The value of the hotel is $100 \%$ of the income per capita or the equivalent in local currency of USD 200,000 , whichever is greater.

- The hotel has a loan from a domestic bank, secured by a mortgage over the hotel's real estate. The hotel cannot pay back the loan, but makes enough money to operate otherwise.

In addition, Doing Business evaluates the quality of legal framework applicable to judicia liquidation and reorganization proceedings and the extent to which best insolvency practices have been implemented in each economy covered. 


\section{Resolving Insolvency - Ukraine}

\begin{tabular}{|c|c|c|c|c|}
\hline Indicator & Ukraine & $\begin{array}{l}\text { Europe \& Central } \\
\text { Asia }\end{array}$ & $\begin{array}{l}\text { OECD high } \\
\text { income }\end{array}$ & $\begin{array}{l}\text { Best Regulatory } \\
\text { Performance }\end{array}$ \\
\hline Recovery rate (cents on the dollar) & 9.0 & 38.5 & 70.2 & 92.9 (Norway) \\
\hline Time (years) & 2.9 & 2.3 & 1.7 & 0.4 (Ireland) \\
\hline Cost (\% of estate) & 40.5 & 13.3 & 9.3 & 1.0 (Norway) \\
\hline Outcome ( 0 as piecemeal sale and 1 as going concern) & 0 & .. & .. & .. \\
\hline Strength of insolvency framework index (0-16) & 8.5 & 11.2 & 11.9 & None in 2018/19 \\
\hline
\end{tabular}

Figure - Resolving Insolvency in Ukraine - Score

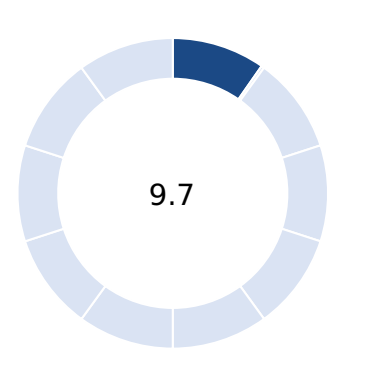

Recovery rate

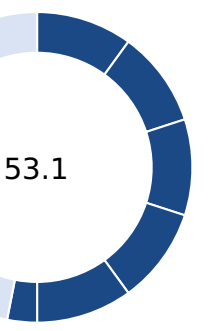

Strength of insolvency framework index

Figure - Resolving Insolvency in Ukraine and comparator economies - Ranking and Score

DB 2020 Resolving Insolvency Score

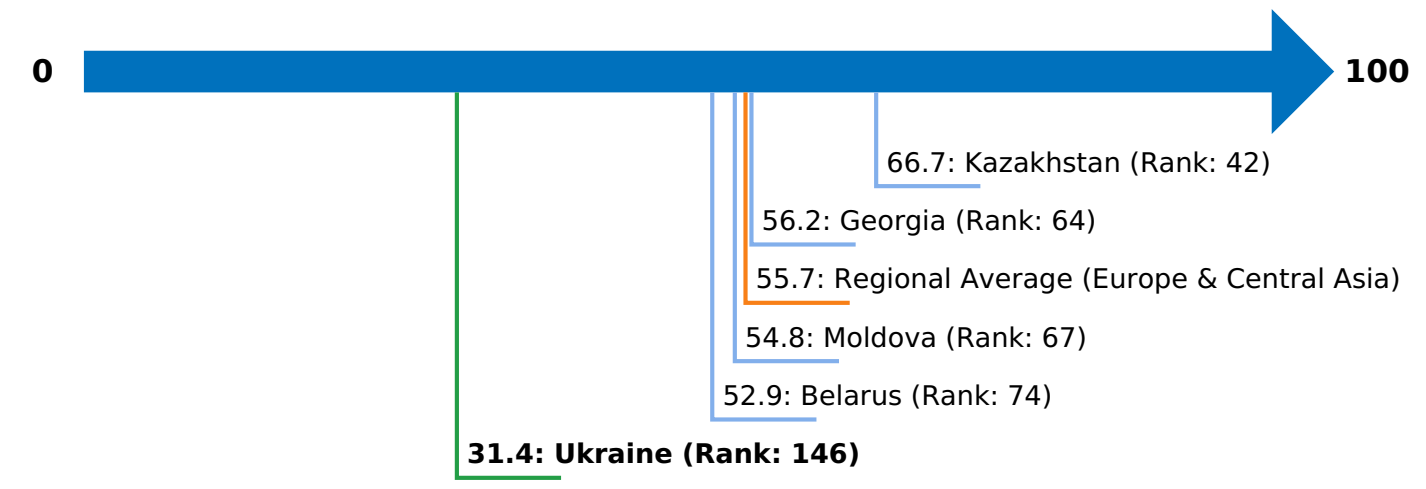

Note: The ranking of economies on the ease of resolving insolvency is determined by sorting their scores for resolving insolvency. These scores are the simple average of the scores for the recovery rate and the strength of insolvency framework index. 
Figure - Resolving Insolvency in Ukraine - Time and Cost

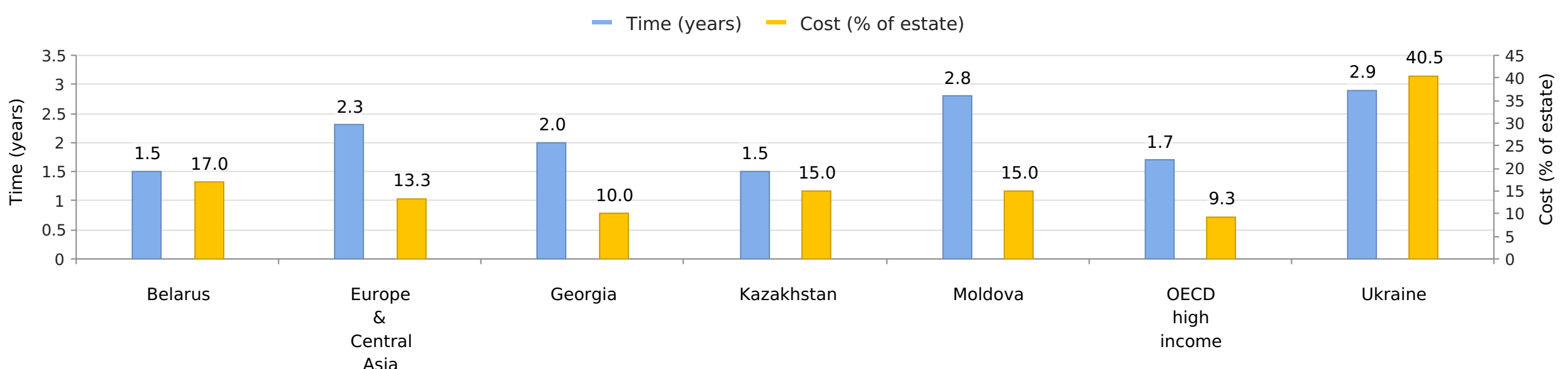




\section{Figure - Resolving Insolvency in Ukraine and comparator economies - Measure of Quality}

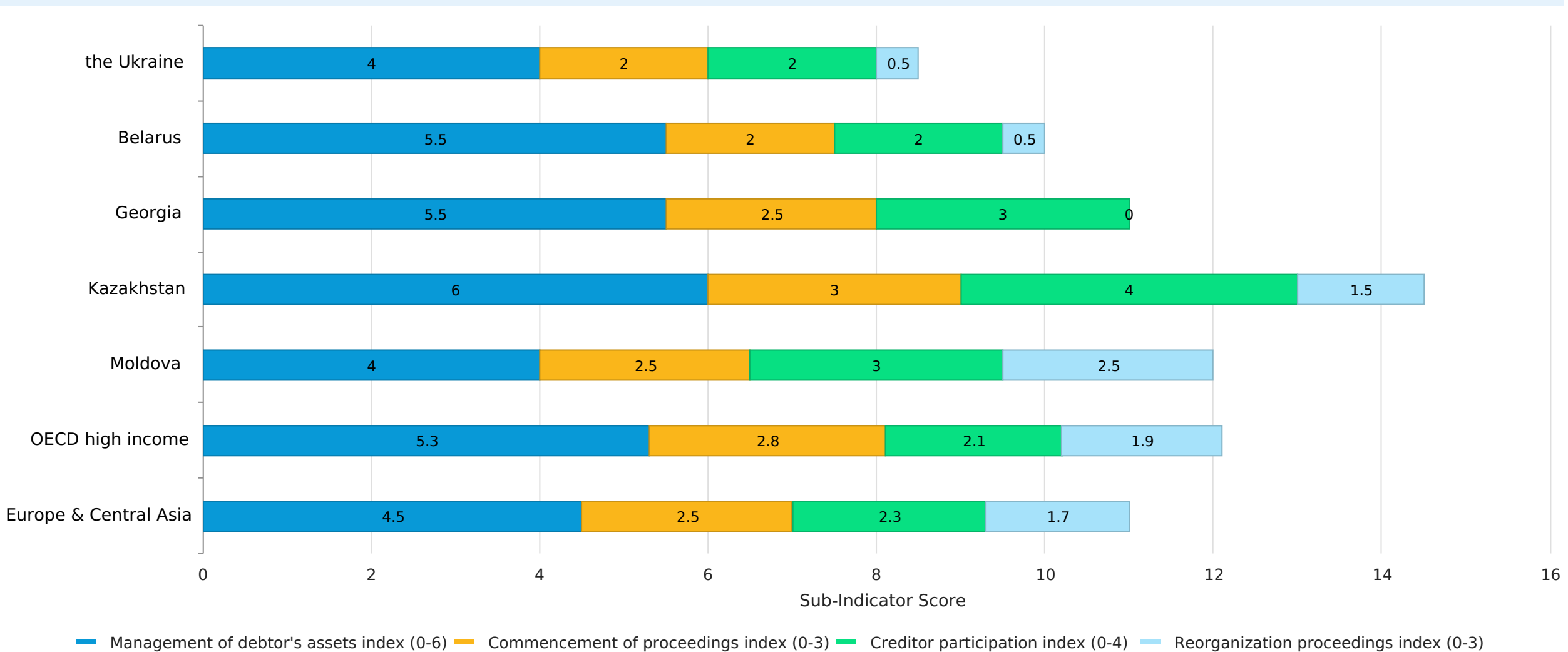

Note: Even if the economy's legal framework includes provisions related to insolvency proceedings (liquidation or reorganization), the economy receives 0 points for the strength of insolvency framework index, if time, cost and outcome indicators are recorded as "no practice."

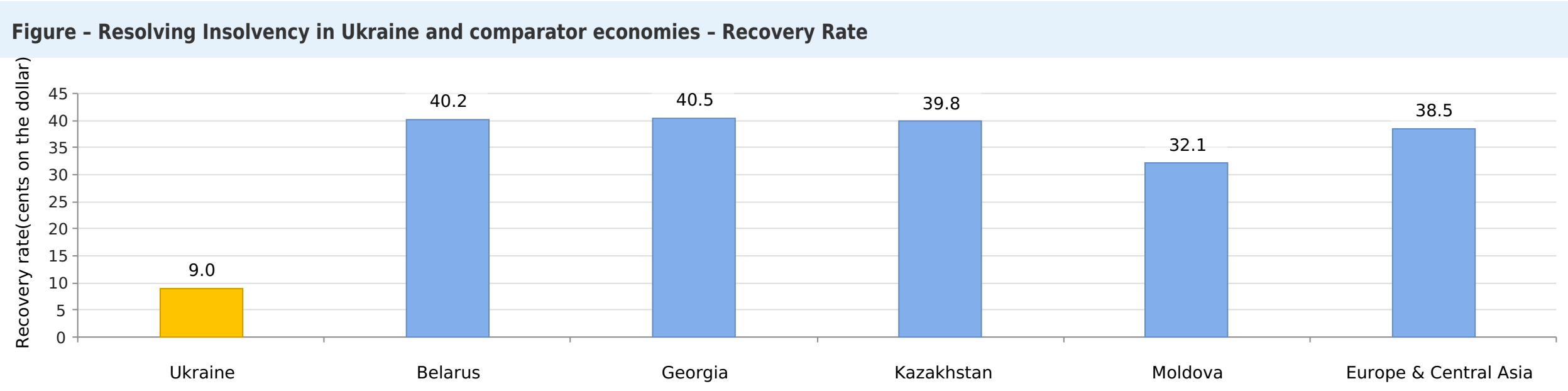




\section{Details - Resolving Insolvency in Ukraine}

\section{Indicator}

Proceeding

attempt at
reorganization)

Time (in years)

2.9

Recovery rate

(cents on the dollar)

Outcome piecemeal sale

Cost (\% of estate)

40.5
Score

Under current Ukrainian insolvency legislation (Articles 5-6 of the Bankruptcy Law), Mirage's management can initiate pre-insolvency restructuring proceedings, but it needs BizBank's consent. BizBank is likely not to agree to such proceedings because it would be more interested in recovering its loan through foreclosure as soon as possible. Therefore, in order to prevent the foreclosure by BizBank against Mirage's property (and, as a result, an immediate sale of Mirage's property piecemeal), Mirage will initiate insolvency proceedings. According to Article 19 of the Bankruptcy Law, once Mirage's management initiates insolvency proceedings, all enforcement actions for claims which arose prior to filing for insolvency will be stayed for the entire duration of the proceedings and no penalties will be added to the existing claims. However, it is unlikely that Mirage's solvency can be restored and restructured during the reorganization proceedings. As a result, the commercial court will declare Mirage bankrupt and initiate liquidation proceedings.

As part of the liquidation proceedings, the insolvency administrator will attempt to sell the hotel's assets in order to satisfy the creditors' claims. It is very unlikely that a purchaser can be found willing to buy the hotel as a whole and continue operating it. Therefore, the assets of the hotel will most likely be sold piecemeal at an auction and the buyer will take possession of them.

Mirage's management will initiate insolvency proceedings, which will stay all enforcement actions for claims which arose prior to filing for insolvency filing (Art. 19 of the Bankruptcy Law). The court will notify the creditors through a public announcement. Creditors will file their claims within a 30-day period (Art. 23 of the Bankruptcy Law). The court will appoint an insolvency administrator who will review the creditors' claims and submit a report with the results of the review to the court's approval. After the decision by the court, the insolvency administrator will notify the creditors whether their claims were accepted or rejected and the list of creditors' claims will be composed. After the list of creditors' claims is finalized, the first meeting of the creditors will be held, where the creditors will decide whether to liquidate Mirage or to proceed with restructuring proceedings. If the creditors cannot agree on the course of action, the court will make a decision to liquidate the company. After the decision to liquidate the company is made, an evaluation of the assets will be made and the assets will be sold piecemeal. Reorganization procedure is limited to 6 months, but can be extended on the request of the administrator for up to 12 months. The liquidation phase can take 12-24 months. The main delays in liquidation will be caused by multiple challenges of procedural acts.

The cost associated with the entire proceedings would amount to approximately $40.5 \%$ of the value of the debtor's estate. The major expenses are comprised of court's fees (2.5\%), attorneys' fees (13\%), fees of the insolvency representative (9\%), fees of other professionals involved in the case (around 7\%), auctioneer's fees (8\%). Other fees are around $1 \%$. 


\section{Details - Resolving Insolvency in Ukraine - Measure of Quality}

Answer

Score

Strength of insolvency framework index (0-16)

Commencement of proceedings index (0-3)

2.0

What procedures are available to a DEBTOR when commencing insolvency proceedings?

(b) Debtor may file for $\quad 0.5$

liquidation only

Does the insolvency framework allow a CREDITOR to file for insolvency of the debtor?

(b) Yes, but a creditor

may file for liquidation only

What basis for commencement of the insolvency proceedings is allowed under the insolvency framework? (a) Debtor is generally unable to pay its debts as they mature (b) The value of debtor's liabilities exceeds the value of its assets

(a) Debtor is

rally unable to pay its debts as they mature

\section{Management of debtor's assets index (0-6)}

4.0

Does the insolvency framework allow the continuation of contracts supplying essential goods and services to the Yes debtor?

Does the insolvency framework allow the rejection by the debtor of overly burdensome contracts?

Yes 1.0

Does the insolvency framework allow avoidance of preferential transactions?

Yes 1.0

Does the insolvency framework allow avoidance of undervalued transactions?

Yes

(1)

Does the insolvency framework provide for the possibility of the debtor obtaining credit after commencement of No insolvency proceedings? 1.0

Does the insolvency framework assign priority to post-commencement credit?

(c) No priority is assigned to post-

commencement

creditors

Reorganization proceedings index (0-3)

Which creditors vote on the proposed reorganization plan?

(c) Other

0.5

Does the insolvency framework require that dissenting creditors in reorganization receive at least as much as No

0.0

what they would obtain in a liquidation?

Are the creditors divided into classes for the purposes of voting on the reorganization plan, does each class vote No separately and are creditors in the same class treated equally?

Creditor participation index (0-4)

Does the insolvency framework require approval by the creditors for selection or appointment of the insolvency No representative?

0.0

Does the insolvency framework require approval by the creditors for sale of substantial assets of the debtor?

Yes

1.0

Does the insolvency framework provide that a creditor has the right to request information from the insolvency

No

0.0 representative?

Does the insolvency framework provide that a creditor has the right to object to decisions accepting or rejecting Yes creditors' claims?

Note: Even if the economy's legal framework includes provisions related to insolvency proceedings (liquidation or reorganization), the economy receives 0 points for the strength of insolvency framework index, if time, cost and outcome indicators are recorded as "no practice." 


\section{$\because$ Employing Workers}

Doing Business presents detailed data for the employing workers indicators on the Doing Business website (http://www.doingbusiness.org). The study does not present rankings of economies on these indicators or include the topic in the aggregate ease of doing business score or ranking on the ease of doing business

The most recent round of data collection was completed in May 2019. See the methodology for more information.

\section{What the indicators measure}

\section{Hiring}

(i) whether fixed-term contracts are prohibited for permanent tasks; (ii) maximum cumulative duration of fixed-term contracts; (iii) length of the maximum probationary period; (iv) minimum wage; (v) ratio of minimum wage to the average value added per worker.

\section{Working hours}

(i) maximum number of working days allowed per week; (ii) premiums for work: at night, on a weekly rest day and overtime; (iii) whether there are restrictions on work at night, work on a weekly rest day and for overtime work; (iv) length of paid annual leave.

\section{Redundancy rules}

(i) whether redundancy can be basis for terminating workers; (ii) whether employer needs to notify and/or get approval from third party to terminate 1 redundant worker and a group of 9 redundant workers; (iii) whether the law requires employer to reassign or retrain a worker before making worker redundant; (iv) whether priority rules apply for redundancies and reemployment.

\section{Redundancy cost}

(i) notice period for redundancy dismissal; (ii) severance payments, and (iii) penalties due when terminating a redundant worker. Data on the availability of unemployment protection for a worker with one year of employment is also collected.

\section{Case study assumptions}

To make the data comparable across economies, several assumptions about the worker and the business are used.

\section{The worker:}

- Is a cashier in a supermarket or grocery store, age 19, with one year of work experience.

- Is a full-time employee.

- Is not a member of the labor union, unless membership is mandatory.

\section{The business:}

- Is a limited liability company (or the equivalent in the economy).

- Operates a supermarket or grocery store in the economy's largest business city. For 11 economies the data are also collected for the second largest business city.

- Has 60 employees.

- Is subject to collective bargaining agreements if such agreements cover more than $50 \%$ of the food retail sector and they apply even to firms that are not party to them.

- Abides by every law and regulation but does not grant workers more benefits than those mandated by law, regulation or (if applicable) collective bargaining agreements.

\section{Employing Workers - Ukraine}

\section{Details - Employing Workers in Ukraine}

Answer

Hiring

Fixed-term contracts prohibited for permanent tasks?

Yes

Maximum length of a single fixed-term contract (months)

No limit

Maximum length of fixed-term contracts, including renewals (months)

No limit

Minimum wage applicable to the worker assumed in the case study (US\$/month)

135.1

Ratio of minimum wage to value added per worker

0.4

Maximum length of probationary period (months)

\section{Working hours}

Standard workday

Maximum number of working days per week

Premium for night work (\% of hourly pay)

Premium for work on weekly rest day (\% of hourly pay)

Premium for overtime work (\% of hourly pay)

Restrictions on night work?

No

Restrictions on weekly holiday?

Yes

Restrictions on overtime work?

Yes 


\section{Redundancy rules}

Dismissal due to redundancy allowed by law?
Third-party notification if one worker is dismissed?
Third-party approval if one worker is dismissed?
Third-party notification if nine workers are dismissed?
Third-party approval if nine workers are dismissed? No
Retraining or reassignment obligation before redundancy?
Priority rules for redundancies?

Priority rules for reemployment?

Redundancy cost

Notice period for redundancy dismissal for a worker with 1 year of tenure (weeks of salary) 


\section{Business Reforms in Ukraine}

From May 2, 2018 to May 1, 2019, 115 economies implemented 294 business regulatory reforms across the 10 areas measured by Doing Business. Reforms inspired by Doing Business have been implemented by economies in all regions. The following are reforms implemented since Doing Business 2008.

$\checkmark=$ Doing Business reform making it easier to do business. ${ }^{\times}=$Change making it more difficult to do business.

\section{DB2020}

$\checkmark$ Dealing with Construction Permits: Ukraine streamlined dealing with construction permits process by eliminating the requirement to hire an external supervisor and introducing an online notification system. Ukraine also made obtaining a construction permit less costly by reducing the contribution fee to the Kyiv City Council.

$\checkmark$ Getting Electricity: Ukraine made getting electricity easier by streamlining the issuance of technical conditions and by implementing a geographic information system. Ukraine also improved the reliability of power supply by introducing an outage compensation mechanism.

$\checkmark$ Registering Property: Ukraine made registering property easier by increasing the transparency of the land administration system.

Getting Credit: Ukraine improved access to credit information by establishing a new public credit registry in the National Bank of Ukraine.

Protecting Minority Investors: Ukraine strengthened minority investor protections by requiring greater disclosure of transactions with interested parties.

$\checkmark$ Trading across Borders: Ukraine reduced the time to import by simplifying conformity certification requirements for auto parts.

\section{DB2019}

$\times$ Dealing with Construction Permits: Ukraine made construction permitting more costly by increasing the contribution fee to the city social and engineering-transport infrastructure. On the other hand, Ukraine made dealing with construction permits easier by eliminating a requirement that investors obtain clearance from the State Service of Ukraine for Emergency Situations.

Protecting Minority Investors: Ukraine strengthened minority investor protections by increasing the requirements for the disclosure in annual reports of related-party transactions.

$\checkmark$ Trading across Borders: Ukraine made trading across borders easier by eliminating the verification requirement on auto parts from the State Service of Export Control.

Enforcing Contracts: Ukraine made enforcing contracts easier by introducing a simplified procedure for small claims and pre-trial conferences as part of the case management techniques used in all commercial courts.

\section{DB2018}

$\checkmark$ Dealing with Construction Permits: Ukraine made dealing with construction permits easier by reducing fees.

Protecting Minority Investors: Ukraine strengthened minority investors protections by requiring detailed immediate public disclosure of related-party transactions.

$\checkmark$ Paying Taxes: Ukraine made paying taxes easier by reducing the rate for the unified social contribution tax.

\section{DB2017}

$\checkmark$ Protecting Minority Investors: Ukraine strengthened minority investor protections by requiring interested director or shareholder to be excluded from the vote, by requiring that proposed related-party transactions undergo external review, by introducing remedies in cases where related-party transactions are harmful to the company and also clarifying ownership and control structures.

$\checkmark$ Enforcing Contracts: Ukraine made enforcing contracts easier by introducing a system that allows users to pay court fees electronically

DB2016

$\checkmark$ Starting a Business: Ukraine made starting a business easier by reducing the time required for VAT registration and by eliminating business registration fees.

DB2015

$\checkmark$ Paying Taxes: Ukraine made paying taxes easier for companies by introducing an electronic system for filing and paying labor taxes. On the other hand, it increased the environmental tax. 
DB2014

$\checkmark$ Starting a Business: Ukraine made starting a business easier by eliminating the requirement for registration with the statistics authority and by eliminating the cost for value added tax registration.

$\checkmark$ Dealing with Construction Permits: Ukraine made dealing with construction permits easier by introducing a risk-based approval system, eliminating requirements for certain approvals and technical conditions and simplifying the process for registering real estate ownership rights.

$\checkmark$ Getting Electricity: Ukraine made getting electricity easier by streamlining the process for obtaining a new connection.

$\checkmark$ Registering Property: Ukraine made transferring property easier by streamlining procedures and revamping the property registration system.

$\checkmark$ Getting Credit: Ukraine improved access to credit information by collecting data on firms from financial institutions.

$\checkmark$ Paying Taxes: Ukraine made paying taxes easier for companies by simplifying tax returns and further improving its electronic filing system.

$\checkmark$ Trading across Borders: Ukraine made trading across borders easier by releasing customs declarations more quickly and reducing the number of physical inspections.

$\checkmark$ Resolving Insolvency: Ukraine made resolving insolvency easier by strengthening the rights of secured creditors, introducing new rehabilitation procedures and mechanisms, making it easier to invalidate suspect transactions and shortening the statutory periods for several steps of the insolvency process.

\section{DB2013}

$\checkmark$ Starting a Business: Ukraine made starting a business easier by eliminating the minimum capital requirement for company incorporation as well as the requirement to have incorporation documents notarized.

$\checkmark$ Registering Property: Ukraine made property transfers faster by introducing an effective time limit for processing transfer applications at the land cadastre in Kiev.

$\checkmark$ Paying Taxes: Ukraine made paying taxes easier by implementing electronic filing and payment for medium-size and large enterprises.

\section{DB2012}

Starting a Business: Ukraine made starting a business easier by eliminating the requirement to obtain approval for a new corporate seal.

$\checkmark$ Paying Taxes: Ukraine made paying taxes easier and less costly for firms by revising and unifying tax legislation, reducing corporate income tax rates and unifying social security contributions.

$\times$ Trading across Borders: Ukraine made trading across borders more difficult by introducing additional inspections for customs clearance of imports.

$\checkmark$ Enforcing Contracts: Ukraine amended legislation to streamline commercial dispute resolution and increase the efficiency of enforcement procedures.

$\checkmark$ Resolving Insolvency: Ukraine amended its legislation on enforcement, introducing more guarantees for secured creditors.

\section{DB2011}

$\checkmark$ Starting a Business: Ukraine eased business start-up by substantially reducing the minimum capital requirement.

$\checkmark$ Dealing with Construction Permits: Ukraine made dealing with construction permits easier by implementing national and local regulations that streamlined procedures.

$\checkmark$ Paying Taxes: Ukraine eased tax compliance by introducing and continually enhancing an electronic filing system for value added tax.

\section{DB2010}

$\checkmark$ Protecting Minority Investors: Ukraine strengthened investor protections through a new joint stock companies law enhancing approval requirements for related-party transactions, increasing disclosure requirements in the annual report and making it easier to sue directors in cases where related-party transactions harm the company.

\section{DB2009}

$\times$ Dealing with Construction Permits: Dealing with construction permits in Ukraine became more costly because of the introduction of an infrastructure tax and more time consuming because of an administrative backlog.

$\checkmark$ Getting Credit: Ukraine improved access to credit information by creating a new private credit bureau.

$\checkmark$ Paying Taxes: Ukraine made paying taxes less costly for companies by reducing employers' contribution rate to the pension fund-though it also increased their contribution rates to the social security fund and social insurance for work accidents.

$\checkmark$ Trading across Borders: Ukraine reduced the time for importing by improving port infrastructure and services. 


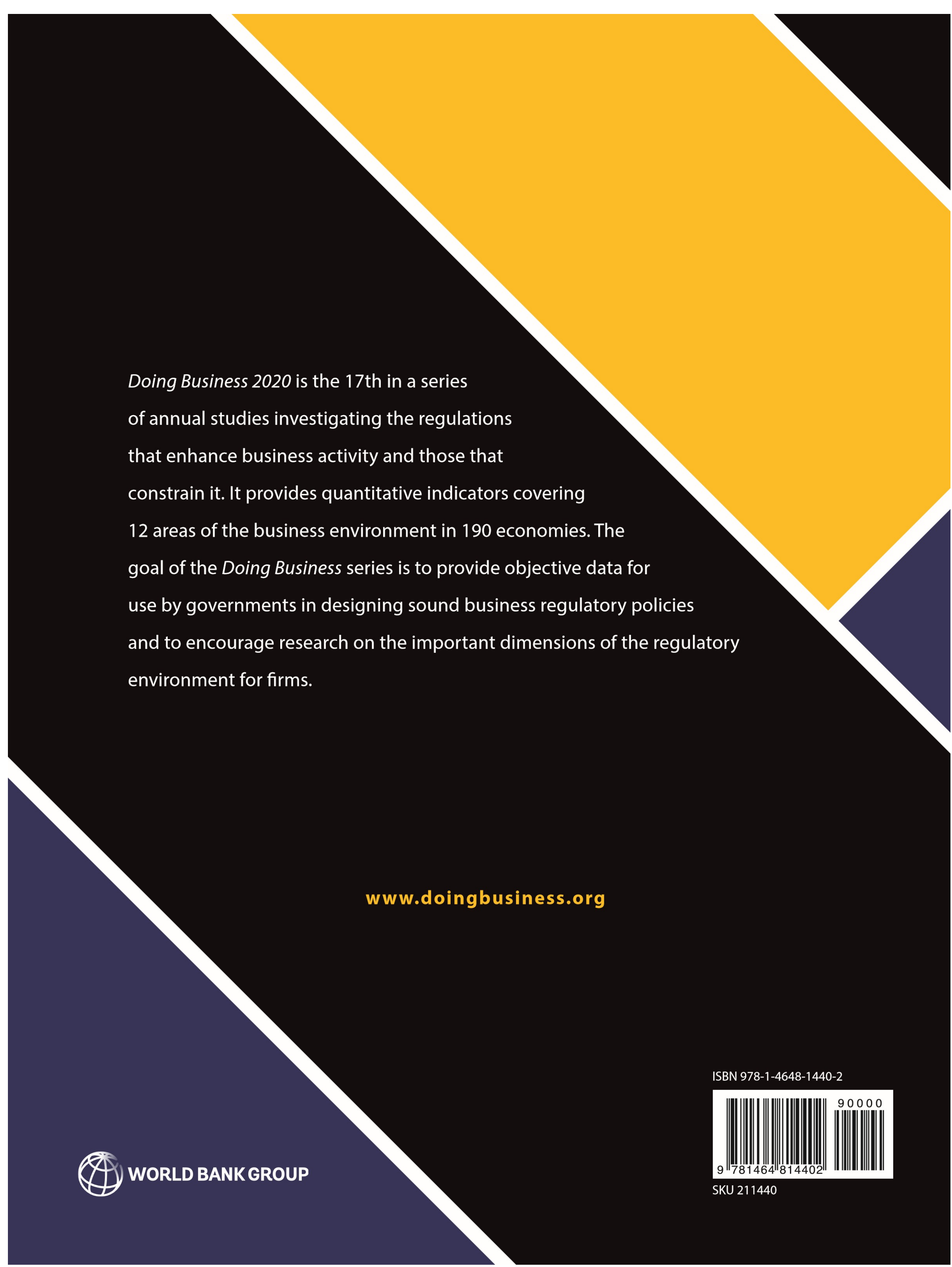

